\title{
A COPERNICAN VIEW OF HEALTH CARE ANTITRUST
}

\author{
William M. SAGE* AND PETER J. HAMMER**
}

\begin{abstract}
Diligent reader, in this work, which has just been created and published, you have the motions of the fixed stars and planets, as these motions have been reconstituted on the basis of ancient as well as recent observations, and have moreover been embellished by new and marvelous hypotheses. You also have most convenient tables, from which you will be able to compute those motions with the utmost ease for any time whatever. Therefore buy, read, and enjoy [this work].
\end{abstract}

Nicholas Copernicus ${ }^{1}$

INTRODUCTION

Is the Health Care Revolution finished? This question is open to a variety of interpretations. "Finished" can mean completed; it can also mean terminated. "Revolution" can signify a fundamental change in ways of thinking, paradigms, or frames of reference; it can also denote a geometric path that eventually returns to its starting point. Indeed, modern eyes can read a similar double entendre into the title of Nicholas Copernicus' sixteenth century masterwork, On the Revolutions. On the one hand, Copernicus catalogued with loving precision the positions of planets in their orbits, among the most conservative and consistent of natural phenomena. On the other hand, the Polish astronomer's simple diagrams and concise narrative passages quietly but insistently challenged-and eventually overturned-long-held and deeply cherished beliefs about the origin, significance, and destiny of mankind.

This article makes no claim to insights of Copernican dimension. Still, the transformation in scientific thought that led scholars to reject the geocentric (earth-centered) model of the known universe that had prevailed since ancient times in favor of a heliocentric (sun-centered) model is an apt metaphor for attempts to harmonize the incompletely theorized blend of competition and

Copyright (c) 2002 by William M. Sage and Peter J. Hammer

This article is also available at http://www.law.duke.edu/journals/65LCPSage.

* Professor of Law, Columbia University. Visiting Professor, Duke University School of Law, Spring 2001.

** Assistant Professor of Law, University of Michigan. Visiting Scholar, Duke University School of Law, Spring 2001.

This article is part of a larger project, "Competing on Quality of Care: Comparing Antitrust Law to Market Reality," supported by an Investigator Award in Health Policy Research from the Robert Wood Johnson Foundation. The authors thank Nancy Cooney and Aaron Hovan for research assistance.

1. Nicholas Copernicus, ON the Revolutions XV (Jerzy Dobrzycki ed. \& Edward Rosen trans., Johns Hopkins University Press 1978) (1543). 
regulation that characterizes the contemporary health care system. This article therefore proposes and explores an analogy between Copernican astronomy and American health care. In doing so, it sketches out a new view of "competition policy"-extending beyond traditional antitrust analysis-that may be motivating, if not fully explanatory, for legal scholars and public policy-makers.

The "revolution" that concerns us is the acceptance of competition as a legitimate governing principle for medical services previously allocated via professional (though nonetheless profitable) processes. One can analogize precompetitive, physician-centered conceptions of health care to Ptolemaic models that would eventually be superseded by a "Copernican" health system centered on consumers. Antitrust law played a significant role in this reconceptualization through Supreme Court cases such as American Medical Ass'n v. United States, ${ }^{2}$ Goldfarb v. Virginia State Bar, ${ }^{3}$ Arizona v. Maricopa County Medical Society, ${ }^{4}$ and FTC v. Indiana Federation of Dentists. ${ }^{5}$ However, the complex position of today's health care system in society's grand marketplace strains antitrust enforcement. Prevailing legal doctrine capably dismantles explicit barriers to price competition-so-called "naked restraints on trade"-and usually manages to eliminate restrictions on output that result from the exercise of market power. By contrast, non-price considerations such as quality, choice, and innovation are harder to accommodate in the streamlined competitive models utilized in conventional antitrust analysis.

In part, such limitations are endemic to antitrust law regardless of industry. But they also reflect special problems in antitrust oversight of health care. Having defined itself by its struggle to wrest medical markets from physician control, antitrust law became trapped in a narrow, physician-oriented view of health care competition, and has yet to engage fully with the health care system as it currently exists. Dramatic increases in access to health insurance, medicine's technological capabilities, and public and private health care expenditures not only gave rise to managed care-whose success or demise this symposium invites us to assess-but also widened the gap between the questions that society needs answered about medical competition and the predictive capacity of antitrust law.

A major source of backlash against managed care has been the widespread perception that HMOs' single-minded pursuit of low costs and high profits has left largely unfulfilled their potential to improve quality by delivering preventive services, coordinating care, instituting early treatment, and reducing unnecessary hospitalization and surgery. One would think that quality would be a natural subject for antitrust oversight in a newly competitive marketplace. However, quality-based evaluation of competitive conditions has yet to occur. Neither law nor scholarship in this area has advanced significantly beyond the
2. 317 U.S. $519(1943)$
3. 421 U.S. 773 (1975).
4. 457 U.S. 332 (1982).
5. 476 U.S. 447 (1986). 
cautionary approach of scholars in the 1980s, who feared that permitting the medical profession to assert potential non-price benefits from collective action might undo the fragile gains in price competition that had been achieved. ${ }^{6}$

The erosion of physicians' economic power, coupled with the intense focus of both public and private payers on cost containment over the last two decades, gives us reason to re-examine the prevailing wisdom regarding antitrust and quality-based competition. Our intent is to strengthen antitrust law, not weaken it. In significant part because of antitrust law, health care today features active price competition. Among other things, this allows new antitrust hypotheses to be tested with less risk of merely putting the competitive genie back into the bottle and returning to the days of unquestioned physician hegemony.

Much as Copernicus and his successors were led to revolutionary theory by the desire to explain discordant empirical observations, we come to this article from recently completed empirical research on judicial opinions in health care antitrust litigation. ${ }^{7}$ Our primary goal in that study was to determine whether antitrust law can safeguard non-price dimensions of medical care in an increasingly competitive market. We therefore conducted a comprehensive examination of antitrust enforcement between 1985 and 1999. Using a detailed casecoding instrument as well as careful textual analysis, we reviewed over 500 judicial opinions involving medical antitrust litigation, as well as a smaller number of consent decrees and formal administrative actions.

We reached the following conclusions from our case review. First, courts seldom engage in detailed assessments of quality and non-price concerns. ${ }^{8}$ Second, no cogent theory of nonprice competition has been developed to guide courts in specific cases. ${ }^{9}$ Third, historical factors and legislative interventions often cause courts to divorce quality from competition rather than factoring it into a competitive mix. ${ }^{10}$ Fourth, courts under-utilize analytical tools that are available to them from other disciplines, such as health services research. ${ }^{11}$

We attribute these findings partly to the fact that medical antitrust litigation has not kept pace or direction with changes in the overall health care system. Health care is no longer exclusively a doctor's world, yet antitrust law remains preoccupied with doctors' claims. Most cases involve disputes over medical staff privileges or contracting practices between physicians and hospitals-a

6. Thomas L. Greaney, Competitive Reform in Health Care: The Vulnerable Revolution, 5 YALE J. ON REG. 179 (1988); Thomas L. Greaney, Quality of Care and Market Failure Defenses in Antitrust Health Care Litigation, 21 CONN. L. REV. 605, 665 (1989) (concluding that "courts should approach market failure justifications with caution approaching trepidation") [hereinafter Greaney, Quality of Care].

7. Peter J. Hammer \& William M. Sage, Antitrust, Health Care Quality, and the Courts, 102 COLUM. L. REV. 545 (2002).

8. Id. at 588-93.

9. Id. at $609-11$.

10. Id. at $617-20$.

11. Id. at 621-23. 
pattern largely unchanged from the beginning of our study period to the end. ${ }^{12}$ Consequently, courts continue to focus on overcoming professional resistance to price discounting and corporate control, often still regarding quality as a selfregulatory rather than a consumer issue and depending on professional processes rather than competition to defend quality and promote innovation.

Managed care has not fundamentally altered courts' assumptions regarding nonprice competition. At most-like the refined Ptolemaic models of the universe that remained viable even in Copernicus' time-physician-centered antitrust doctrine has been embellished in various respects to improve its performance in particular competitive circumstances involving nonprice characteristics of health care. Notably, courts have been able in some instances to penetrate the "market failures" that present obstacles to quality-based competition in health care and incorporate their findings into antitrust analysis. In particular, courts have made progress analyzing consumer choice and information as procompetitive nonprice characteristics. ${ }^{13}$ On the other hand, managed care has increased judicial skepticism regarding the motives of insurance companies claiming to be agents of consumers, and may have driven courts back somewhat toward the medical profession (and non-profit hospitals) as patient representatives.

Even when courts analyze quality as a component of health care competition rather than segregating it into regulatory or self-regulatory processes apart from the marketplace, they are likely to apply (either explicitly or implicitly) a demand-side model. In demand-side models, augmenting provider-specific quality increases the price that a provider can charge and/or the volume of patients seeking the provider's services. ${ }^{14}$ Standing alone, demand-side models are incapable of addressing the complete range of nonprice dimensions relevant to medical markets, particularly considerations that, rightly or wrongly, were taken for granted in a professionally dominated health care system but that must now be factored into the competitive mix. These include access to health care, the knowledge base of medical science, innovation, and effects on system stability mediated by individual and collective trust in physicians and other health care providers.

Lessons learned about synergies and tradeoffs between price and nonprice competition potentially apply beyond health care. The cutting edge of antitrust law generally has moved from raw cartels producing commodities and basic

12. Id. at 567-70.

13. Id.; see also, Boczar v. Manatee Hosps. \& Health Sys., 993 F.2d 1514 (11th Cir. 1993) (reinstating jury verdict in favor of obstetrician who offered patients a different style of practice).

14. The invocation of demand-side models also explains why a number of courts have been reluctant to infer the existence of "market power" from evidence of higher medical prices, unadjusted for quality differences. See Doctor's Hosp. of Jefferson, Inc. v. Southeast Med. Alliance, Inc., 123 F.3d 301, 310 (5th Cir. 1997) ("In medical care, it must be remembered, a provider's higher prices are not necessarily indicative of a less competitive market; they may correlate with better services or more experienced providers.”); see also Blue Cross \& Blue Shield v. Marshfield Clinic, 65 F.3d 1406, 1411-12 (7th Cir. 1995) ("Generally, you must pay more for higher quality."). 
search goods to more complex sectors of the economy such as banking and telecommunications. These innovative, quality-dependent, socially important industries are frequently regulated, and may even receive public subsidies for research or service. They are not necessarily "professionalized," even though professionals typically supply experience or credence goods whose nonprice attributes matter to consumers, and the historical dominance of physicians in the economics of American medicine undoubtedly imbues the health care system with "professional" traits. Neither is guild governance sufficient to place a sector of economic activity within our model. For example, medicine may be different for antitrust purposes from other professions, such as law and engineering, even though the early history of antitrust enforcement involving the professions moved in tandem.

In Part II, we elaborate on the Copernican metaphor. Parts III and IV contrast narrow, "Ptolemaic" accounts of health care competition with a "Copernican" array of interpretations and proposals that integrate antitrust doctrine with a broader constellation of regulatory and self-regulatory processes. Using this juxtaposition, we identify issues in health care antitrust where legal doctrine, industry practice, and social preferences diverge, and we describe the contortions courts have used to reconcile them. Our analysis, which is still tentative, is not intended to impose a "super-law" over current institutions. We have neither a deregulatory agenda nor a belief that regulators' noses should be under the competitive tent. We desire only to better define the interface between competition and regulation in health care, and thereby to liberate legal and regulatory actors to consider a wider range of issues than is their wont.

\section{II}

\section{THE COPERNICAN METAPHOR}

An abbreviated description of the Copernican revolution will suffice for purposes of this article. Most of us remember from our years of general education that Nicholas Copernicus earned a prominent place in the history of science by resurrecting the speculation of some early Greek astronomers that the earth and five known planets revolved around the sun. Unlike his ancient predecessors, however, Copernicus backed his (relatively) simple heliocentric hypothesis with precise calculations that produced highly accurate predictions. The result was to demolish a millennium-old account of the universeassociated with Aristotle and the Greek astronomer Ptolemy-that had placed the sun and planets in orbit around the earth. This outcome was all the more controversial because the centrality of earth in the Ptolemaic cosmology had been adopted as gospel for the exaltation of man in Christian belief generally and Catholic dogma specifically. Further, Copernicus' revelation begat even more revolutionary theories by Kepler, Galileo, Bruno, and, eventually, Einstein.

Renaissance astronomy is the epitome of dictum as applied to antitrust law. Several aspects of the seismic shift in scientific thought triggered by Copernicus 
are relevant, however, to our case for adopting a dramatically different perspective on health care competition beyond the basic metaphor of abandoning an exclusively physician-centered view of the health care system. First, the Ptolemaic version of events prevailed for nearly two millennia because it was both plausible and serviceable. Its reign came to an end only because of technical improvements in the ability to measure celestial phenomena and parallel growth in applications for such measurement that demanded still greater precision. Neither can one accurately view its demise as a burst balloon; rather, the Ptolemaic model collapsed under its own weight. ${ }^{15}$ Analogously, advances in both medical care and econometrics over the past half-century have placed greater demands on antitrust policy to generate competition not only on price and output, but also on linear quality, choice, and innovation, and have highlighted the absence of a workable model for evaluating these price-quality and quality-quality tradeoffs. Similarly, the expansion of public funding for health care and the social consequences of restricted access to insurance or services have not been incorporated logically into competition policy, though they indisputably influence the evolution of medical markets.

Second, Copernicus (and his publicists) took great pains to avoid a direct confrontation with the defenders of the Ptolemaic creed. On the Revolutions was not published until the year of Copernicus' death. ${ }^{16}$ The author's preface, addressed to then-Pope Paul III, did not deny the work's iconoclasm but confined it to science rather than religion or politics. ${ }^{17}$ Antitrust law has analogous orthodoxies. The influence of interpretations based on democratic theory, public choice, and the like has receded in recent years, leaving the field to the harsh economics of marginal cost pricing and consumer surplus. Consequently, attempts to incorporate hard-to-monetize constructs such as quality and innovation into antitrust doctrine might be viewed by market supremacists as heretical.

15. As observation improved, the Ptolemaic model required increasing complexity for accurate prediction, including ways that challenged common sense such as epicycles (circular suborbits whose centers are carried around the body being orbited), which were hypothesized to account for the apparent retrograde motion of the planets when seen from earth; eccentrics (circular orbits not centered on the body being orbited); and equants (circular orbits around which planets or the centers of epicycles move uniformly), which were hypothesized to account for apparent changes in planetary velocity. See generally AleXANDre Koyre, The AstronomicAl Revolution: CopernicusKEPLER-BORELLI (1973) (discussing the shift from Ptolemaic to Copernican theories of the universe).

16. It is said that galleys were delivered to him on his deathbed, a work ethic to which all academics might aspire. The essence of Copernicus' heliocentrism was evident in an earlier work, Commentaries, which was probably written in 1512, but did not gain wide circulation. Id. at 25-28.

17. Copernicus wrote to His Holiness that "astronomy is written for astronomers," COPERNICUS, supra note 1, at 5, and qualified the self-promotional epigraph that begins this article with the warning, "Let no one untrained in geometry enter here." Id. at XV. Andreas Osiander, a Copernican apologist who penned the foreword to the first edition of On the Revolutions, went farther still, asserting that the heliocentric theory was merely a predictive shorthand, not a claim to scientific truth: "For these hypotheses need not be true nor even probable. On the contrary, if they provide a calculus consistent with the observations, that alone is enough." Id. The Pope appears to have been placated, but other religious figures, John Calvin among them, may not have been. See EdWARD Rosen, Copernicus AND HIS SUCCESSORS 161-72 (1995) (discussing the historical validity of various anti-Copernican statements attributed to John Calvin). 
Not to be disingenuous, any approach that allows regulatory modifications of supposedly free competition indeed risks reintroducing through a quasi-economic back door softer "social considerations" no longer welcome at the front entrance. ${ }^{18}$ On the other hand, the Copernican disclaimer seems warranted to the extent that courts (and even regulators) apply the lessons of a more nuanced competition policy carefully to specific cases and controversies, rather than indulging in sweeping pronouncements about the social costs and benefits of marketplace activities.

Third, a beneficial side-effect of Copernican heliocentrism was to put earth on the same footing as the other planets, avoiding the need to model its behavior as a special case that cannot be informed by observation of non-terrestrial bodies. The debate over whether health care is different from other goods and services traded in markets has occupied countless commentators of all philosophical bents for several decades. ${ }^{19}$ The post-Goldfarb application of antitrust oversight to health care intensified controversy rather than resolving it, much as one can imagine the theories of Copernicus (or, indeed, Darwin) threatening existing hierarchies of social authority and perceived self-importance. Refining competition theory to account for nonprice concerns, including societal as well as consumerist perspectives, might help reconcile these perspectives by allowing health care to be analyzed on a par with other regulated and recently deregulated industries. If one can identify universal attributes of quality or social welfare that can be factored into competitive analysis, the uniqueness of health care truly becomes moot for antitrust purposes.

Fourth, in some ways, Copernican theory was more, rather than less, difficult for an astronomical observer on earth to employ because its predictions were based on a frame of reference (the sun) that was not the observer's. Competitive models of health care centered on consumers rather than physicians suffer from analogous disadvantages because professional opinion tends to be much more accessible than direct empirical measurements of market preferences. Expanding health care antitrust analysis to capture a broader range of issues and objectives than price-output competition may further complicate the task of judging. Regardless of the elegance of any such theory, the judicial frame of reference is defined by the parties to a given dispute, for whom traditional economic-analytic tools may be preferable to a "meta-picture" of competition policy. Moreover, whereas Copernicus could admonish those untrained

18. One bridge between Ptolemaic and Copernican world-views in this respect is the extreme version of Chicago School antitrust economics, which maintains that markets function so well if left to their own devices that antitrust enforcement only becomes necessary when government itself has done something to interfere with market forces. This argument provides a theoretical justification for coordinating antitrust enforcement with substantive oversight in regulated industries. See generally Robert H. Bork, THE ANTITRUst PARAdOX: A POLICY AT WAR With ITSELF (1978) (expounding the Chicago School view).

19. Compare, e.g., Thomas Rice, THE Economics OF HeAlth Reconsidered (1998) (criticizing the belief that market competition yields better public policy outcomes in health care than government control) with RichaRD A. EPSTEIN, MORTAL PERIL: OUR INALIENABle Right TO HEALTH CARE? (1997) (criticizing government efforts to expand access to health care). 
in geometry not to enter the province of astronomy, the antitrust courthouse door is open to all levels of economic sophistication (or lack thereof).

Finally, Copernicus was wrong. It took Johannes Kepler to recognize that planetary orbits were not circular but elliptical, with the sun lying at one focus. By suggesting that price-output analysis represents an incomplete and misguided model of health care competition, we are therefore placing ourselves in Kepler's shoes as much as those of Copernicus. The genesis of Copernicus' error is as interesting as the fact of its occurrence. Copernicus intended his theory to confirm the "natural perfection" of circles and spheres, not merely to demonstrate the superiority of a heliocentric model for the solar system. ${ }^{20}$ Ironically, this preoccupation forced him to reintroduce epicycles and eccentrics to his model even though they marred its attractiveness by increasing the number of calculations required to predict planetary positions. It is therefore worth asking ourselves whether we cherish analogous beliefs that could simultaneously inspire and sabotage our project. We certainly believe that access to health care has social importance, whatever its competitive significance. Relatedly, we also believe that medical professionalism is not merely an empty vessel. Whether these commitments, or other tacit biases, taint our conclusions is a matter for both introspection and external review.

III

\section{"PtOlemaic" COMPETITION}

Like astronomical models, conceptions of health policy are ultimately grounded in efforts to reconcile observed facts about ourselves and the world with our intuitions and aspirations. Part of this process is inductive, part deductive. Just as ancient astronomy was intertwined with cosmology, modern health policy is connected to deeply held beliefs. Different civilizations grouped the same stars into different constellations with different meanings. Analogously, some countries construct universal health care systems centered on the state while others, such as the United States, accept the pluralism and happenstance of private actors transacting in private markets, albeit with substantial public participation and subsidy. Yet underlying all health care systems are qualitatively similar problems, resources, and objectives. The remainder of this article will describe the way in which antitrust law has evolved an understanding of the relationship between America's unique health care system and these convergent considerations. This section outlines the view of competition that by and large has characterized medical antitrust policy, which this article deems "Ptolemaic." Part IV, which explores the "Copernican" vision, goes beyond the limits of current antitrust policy to account for production-side technological and organizational capabilities and certain collective preferences as well as demand-side market interactions.

20. See Rosen, supra note 17, at 117-26. 
Historically, antitrust law's treatment of medicine and the other "learned professions" is a story of partition. For courts at least, the professions seemingly operated in a separate sphere, apart from the workings of trade and commerce. ${ }^{21}$ American Medical Association v. United States ${ }^{22}$ is an important exception, but one that also tends to confirm courts' reluctance to treat professions like other businesses. The criminal case brought against the American Medical Association and the Medical Society of the District of Columbia for their systematic campaign to undermine the Washington, D.C.-based prepaid Group Health Plan was aggressive even by today's standards. Nevertheless, the Supreme Court upheld the convictions. In doing so, however, the Court carefully avoided the question whether the medical profession itself was engaged in "trade," focusing rather on the business aspects of the Group Health Plan that were alleged to have been restrained. Consequently, the successful prosecutions in American Medical Ass'n did not immediately bring medical or professional conduct more closely in line with behavior expected in other lines of commerce.

The medical profession came before the Court again in 1953, in a case similarly alleging anti-competitive conduct directed against prepaid health care. In United States v. Oregon Medical Society, ${ }^{23}$ however, the Court reverted to a policy of walled-off exclusion. To exercise antitrust jurisdiction over the Oregon State Medical Society Plan required proof of an effect on interstate commerce, and the Court found none. ${ }^{24}$ Though the Court affirmed the dismissal of the government's complaint on the narrow grounds that the district court's factual findings were not clearly erroneous, the opinion illustrates the Court's continued reluctance to view medicine as a business. Noting that "there are ethical considerations where the historic direct relationship between patient and physician are involved which are quite different than the usual considerations prevailing in ordinary commercial matters, ${ }^{25}$ the Court suggested that agreements not to compete between non-profit organizations might be treated deferentially, and contended further that there was no reason to expect compe-

21. See, e.g., FTC v. Raladam Co., 283 U.S. 643, 653 (1931) ("medical practitioners ... follow a profession and not a trade").

22. 317 U.S. $519(1943)$.

23. 343 U.S. 326 (1953). The conduct in Oregon Medical Society differed from that in American Medical Ass'n. Between 1936 and 1941, the Medical Society engaged in a scorched-earth policy against the growth of prepaid plans very similar to the conduct condemned in American Medical Ass'n. See United States v. AMA, 110 F.2d 703, $705-07$ (D.C. Cir. 1940). In 1941, however, the Medical Society shifted tactics and started its own non-profit prepaid plan to compete against the private for-profit alternatives. Consequently, the government's complaint alleged an effort to monopolize the market for prepaid plans, and further challenged a practice where the State Medical Society agreed not to compete against prepaid plans sponsored by County Medical Societies. Oregon Med. Soc., 343 U.S. at 328-30.

24. Oregon Med. Soc., 343 U.S. at 339. Efforts to classify health care as an intrastate concern played almost as important a role in shielding medicine from antitrust scrutiny as did the assertion that the professions were not engaged in trade or commerce. See Summit Health, Ltd. v. Pinhas, 500 U.S. 322, 333-43 (1991) (Scalia, J., dissenting) (arguing that peer review procedures involving a single department of a Los Angeles hospital did not trigger Sherman Act jurisdiction).

25. Oregon Med. Soc., 343 U.S. at 336. 
tition between prepaid insurance plans to yield meaningful economic benefits. ${ }^{26}$ The Court weakly distinguished its earlier decision in American Medical Asso'n, reasoning that the location of the Group Health Plan in Washington, D.C., had automatically subjected it to federal law enforcement. ${ }^{27}$

The Supreme Court did not revisit the issue until 1975, when it ruled in Goldfarb v. Virginia State Bar that lawyers could not set fees collectively for representing homebuyers and sellers. ${ }^{28}$ Coming more than three decades after American Medical Ass' $n$ and involving law rather than medicine, the decision rejected the notion that lay purchasers of professional services were incapable of evaluating price-quality tradeoffs, and thereby signaled a new era in antitrust enforcement against the learned professions. ${ }^{29}$ A stream of cases followed, substantially draining the professions and professionalism of their historical mystique. The first line of the Court's 1986 opinion in FTC v. Indiana Federation of Dentists illustrates the radical transformation in judicial thinking that had occurred: "This case concerns commercial relations among certain Indiana dentists, their patients and the patients' dental health insurers." ${ }^{" 30}$ The business of health care was now, in fact, business. To be sure, Goldfarb's famously ambivalent "footnote 17" reminded readers that the Court had entered uncharted territory and might at some point retreat to a position of deference to collective professional judgment, ${ }^{31}$ but none of the subsequent cases gave any indication that judicial lip service to professionalism had substantive meaning. Rather, the suggestion that professional concerns might justify a uniquely tailored set of antitrust principles was repeatedly marginalized. ${ }^{32}$

26. Id. at 337-38 ("There is not the least proof that duplicating sources of the prepaid certificates would make them cheaper, more available or would result in an improved service or have any beneficial effect on anybody.").

27. Id. at 339 ("Interstate commerce was not necessary to the application of the statute there.").

28. 421 U.S. 773 (1975). In addition to rejecting the argument that the learned professions were not engaged in trade and commerce, the Court rejected claims that the price-fixing agreement did not affect interstate commerce and that it was immune under the state action doctrine. Id. at 786-92.

29. Clark C. Havighurst, Health Care as a (Big) Business: The Antitrust Response, 26 J. HEALTH POL. POL'Y \& L. 939, 940-43 (2001) (describing the seminal role the Goldfarb decision played in opening up the medical profession to antitrust scrutiny and in permitting managed care to take root).

30. FTC v. Ind. Fed'n of Dentists, 476 U.S. 447, 448 (1986) (emphasis added).

31. Footnote 17 reads:

The fact that a restraint operates upon a profession as distinguished from a business is, of course, relevant in determining whether that particular restraint violates the Sherman Act. It would be unrealistic to view the practice of professions as interchangeable with other business activities, and automatically to apply to the professions antitrust concepts which originated in other areas. The public service aspect, and other features of the professions, may require that a particular practice, which could properly be viewed as a violation of the Sherman Act in another context, be treated differently. We intimate no view on any other situation than the one with which we are confronted today.

Goldfarb, 421 U.S. at 788 n.17.

32. See Thomas E. Kauper, The Role of Quality of Health Care Considerations in Antitrust Analysis, 51 LAW \& CONTEMP. PROBS. 273, 281-92 (Spring 1988) (tracing the treatment of footnote 17 from Goldfarb through Indiana Federation), and concluding that professional concerns are only given special consideration to the extent that they affect the appropriate economic analysis of the alleged restraint). 
These early efforts to apply antitrust law to professional markets generated considerable confusion in terms of antitrust doctrine. For example, it is hard to say whether the Court was employing per se analysis, rule of reason analysis, or what ultimately came to be known as "quick look" rule of reason analysis." Regardless of the label, however, the conduct challenged in these cases-mainly price-fixing and concerted refusals to deal-fell close to the core of traditional antitrust liability. ${ }^{34}$ Applied to such behavior, the message was clear: Decisions that had previously been left to professional discretion would now be subject to market discipline and judicial scrutiny. From a policy perspective, this generation of antitrust enforcement was designed to break down long-standing professional resistance to market forces and to encourage price competition. In health care specifically, antitrust enforcement helped new forms of medical and insurance organizations gain access to patients and physicians, and facilitated the emergence of active purchasing strategies such as selective contracting and utilization review.

As managed care came to dominate American health care, however, new facts emerged about the health care enterprise and about the organizations managing it. Much as improved astronomical observation rendered the Ptolemaic universe unwieldy and therefore suspect, so too did heightened awareness of the realities of health care financing and delivery confound at least three major assumptions that had governed traditional antitrust oversight: (1) the central role physicians play in controlling medical markets, (2) the classification of payers as pro-competitive consumer agents, and (3) the belief that price and quality competition will necessarily work in tandem.

\section{A. Assumption 1: Physicians Run (Are) the System}

Antitrust enforcement has assumed that health care is primarily about physicians. This preconception has both an intellectual and a practical heritage. Physicians are undoubtedly the most powerful political force in health care and are also the principal point of contact between the middle class and the health

33. In Arizona v. Maricopa County Medical Society, 457 U.S. 332 (1982), the Court condemned the physicians' maximum fee schedule as per se illegal price-fixing, but proceeded to give fairly detailed rule-of-reason-type consideration to the physicians' proffered justifications. In FTC v. Indiana Federation of Dentists, 476 U.S. 447 (1986), National Collegiate Athletic Ass'n v. Board of Regents, 468 U.S. 85 (1984), and National Society of Professional Engineers v. United States, 435 U.S. 679 (1978), the Court purportedly claimed to be employing rule of reason analysis, but proceeded to condemn the conduct in summary fashion, without giving substantial consideration to the alleged justifications. In California Dental Ass'n v. FTC, 526 U.S. 756 (1999), the Court attempted to clarify the role of "quick look" analysis, although few would claim that the law is substantially more clear in the wake of the Court's opinion.

34. See, e.g., FTC v. Ind. Fed'n of Dentists, 476 U.S. 447 (1986) (collective refusal among dentists to provide insurers $x$-rays that could be used in utilization review efforts); Nat'l Collegiate Athletic Ass'n v. Bd. of Regents, 468 U.S. 85 (1984) (college agreement collectively allocating television broadcast rights); Arizona v. Maricopa County Med. Soc'y, 457 U.S. 332 (1982) (collectively set maximum fee schedule for physician services); Nat'l Soc'y of Prof'l Eng'rs v. United States, 435 U.S. 679 (1978) (ethical canon prohibiting competitive bidding for engineering services); Goldfarb v. Va. State Bar, 421 U.S. 773 (1975) (bar association policy setting minimum prices for particular services). 
care system. Accordingly, early accounts of medical economics were iatro-centric, emphasizing physicians' authority to determine the course of treatment for patients and the potential for medical ethics to overcome information market failure. ${ }^{35}$ With respect to the courts' experience specifically, more than twothirds of the medical antitrust disputes decided between 1985 and 1999 involved physicians' relationships with hospitals. ${ }^{36}$

Perceived physician dominance has several implications for antitrust enforcement involving quality. First, because physician-determined quality is amenable to licensing, direct regulation, self-regulation, malpractice litigation, and other influences apart from competition, antitrust courts arguably felt comfortable leaving such a complex subject to better-qualified governmental and quasi-governmental processes. Second, physicians accustomed to unquestioned authority tended to commit flagrant rather than subtle antitrust abuses, so that the courts' time was well spent dislodging these habits and opening medicine to price competition. Third, most physician-initiated suits challenged hospitals' exclusive contracting and staff-privilege decisions, seldom raised serious antitrust issues, and typically were dismissed in the early stages of litigation. ${ }^{37}$ As a result, physicians were generally not perceived as credible antitrust plaintiffs, even (perhaps especially) when claiming injury to quality.

These tendencies are well illustrated by the staff privileges cases, which remain the most common type of medical antitrust litigation. Typically, a physician whose privilege to practice at a particular hospital has been denied, limited, or terminated by the existing medical staff of physicians claims an unlawful boycott by competitors. In nearly all of these cases, courts regard the medical staff's action as quality-motivated and, therefore, a legitimate exercise of regulatory and self-regulatory prerogatives. When plaintiffs prevail, as they do in a handful of instances, it is by showing that rivals' personalities and pocketbooks, not patients' welfare, led to their injuries. ${ }^{38}$ Staff privileges disputes therefore reinforced the perception among judges that antitrust law is an unlikely forum for improving physician practice, and that physician quality is a regulatory concern distinct from market competition. The superficial resemblance of staff privileges actions to state licensing decisions probably predisposed courts to this approach. Both actions serve to truncate the quality curve so that physicians practicing below a certain standard are unavailable to consumers as a market option rather than offering lower quality at a potentially cheaper price.

Times, however, are changing. Hospitals are increasingly geared to satisfying insurer-not physician-demands, which shifts the basis of competition from providing technology, capacity, and amenities to achieving consistent

35. Kenneth J. Arrow, Uncertainty and the Welfare Economics of Medical Care, 53 AM. ECON. REV. 941, 947, 965-66 (1963).

36. Hammer \& Sage, supra note 7, at 566. The percentage was likely even higher before 1985.

37. Id. at 567-70, 574-78.

38. See, e.g., Patrick v. Burget, 486 U.S. 94 (1988) (upholding $\$ 2$ million award in favor of surgeon whose hospital privileges were terminated at the urging of his former partners). 
quality at lower prices. ${ }^{39}$ Our empirical study revealed a trend in the 1990s toward greater "inter-brand" competition among hospitals, achieved in part by entering into exclusive contracts with physicians to staff hospital departments. ${ }^{40}$ Unlike most staff privileges cases, which tend to partition competition from quality, courts hearing exclusive contracting cases by and large have recognized the importance of quality to hospitals' competitive positions. ${ }^{41}$ Exclusive contracting cases, therefore, provide a more promising point of departure for constructing a Copernican framework for antitrust law.

Physician dominance of the health care system is being undermined by other forces as well. Home health care and durable medical equipment have become big business, drug companies are focusing less on physician detailing and more on insurer formularies and direct-to-consumer advertising, pharmaceutical and biotechnological innovation is accelerating, the dietary supplement market is booming, and patients are broadening the care they seek to include a host of alternative practitioners. What accounts for increases in the size and influence of the nonphysician sectors? Surprisingly, the answer is mainly Medicare (and to a lesser extent Medicaid), which opened a fire hydrant of public funding and initiated a positive feedback loop of increasing economic and political power for a host of corporate, institutional, and professional interests. Through effects on health care costs mediated both by availability and use of medical technologies and by cross-subsidization from privately insured patients, public insurance programs bear responsibility as well for some of the dramatic power shift from physicians to private insurers under managed care.

The degree to which the health care system revolves around physicians is important not only to competition based on linear quality, but to the economic and antitrust significance of "choice." Although the medical profession's "ethical" commitment to maintaining free choice of physician always had a dark economic underbelly, ${ }^{42}$ this commitment combined with state regulatory mandates and federal reimbursement rules regarding hospital participation in insurance to make choice an inherent attribute of American health care rather than a

39. This trend is beginning to be recognized in other areas of health law as well. For example, the Internal Revenue Service has relaxed its limitations regarding physician participation on boards of trustees of tax-exempt hospitals and no longer automatically regards physicians as "insiders" when scrutinizing such hospitals for private inurement.

40. Hammer \& Sage, supra note 7, at 569, 580; see also Peter J. Hammer, How Doctors Became Distributors: A Fabled Story of Vertical Relations, 14 LOY. CONSUMER L. REP. (forthcoming 2002) [hereinafter Hammer, How Doctors Became Distributors].

41. See, e.g., Martin v. Mem'l Hosp., 130 F.3d 1143, 1150 (5th Cir. 1997) (opining that exclusivity improves quality control); White v. Rockingham Radiologists, Ltd., 820 F.2d 98, 105 (4th Cir. 1987) ("[B]y making one group responsible and accountable to [the hospital], ... it minimizes its malpractice exposure, [and] can better monitor operations and quality control.").

42. See Charles D. Weller, "Free Choice" as a Restraint of Trade in American Health Care Delivery and Insurance, 69 IOWA L. REV. 1351 (1984) (identifying the anti-competitive effects of the AMA's "ethical" condemnation of limitations on choice of physician); see also PAUL STARR, THE SOCIAL TRANSFORMATION OF AMERICAN MEDICINE 299-300 (1982) (describing the environment articulated in 1934 by the AMA in which private insurance might "ethically" operate and noting that "[i]n the name of free choice, it effectively eliminated the possibility of competition"). 
potential competitive dimension. Managed care brought choice back into the competitive mix. Selective contracting initially was accepted as a legitimate management strategy because of the potential to negotiate price reductions with hospitals and physicians in exchange for assurances of patient volume (an essential linkage for demand-side models of medical competition). It was also accepted because coordination of care, like utilization review, was thought to offer quality improvements. By the mid-1990s, however, restrictions on choice came to be seen as an obvious price-quality tradeoff, most dramatically through the "Harry-and-Louise" lobbying campaign conducted by the insurance industry against the Clinton administration's proposed Health Security Act. For this reason, the economic boom of the late 1990s manifested itself in managed care as a movement away from discrete, tightly integrated HMOs and toward broad provider networks. ${ }^{43}$ Emphasizing choice of physician as a competitive benefit is to some degree in tension with the notion of moving away from a physiciandefined health system, but it reinforces the idea that physicians are merely an input to the health care product (albeit a critical one), not the product itself.

In the aggregate, this recalibration of the health care system away from exclusive physician control raises two questions. One, how should antitrust law adapt its quality-related approach to conduct by hospitals, insurers, pharmaceutical companies, and others who may differ from physicians in corporate form, profit orientation, professionalism, and state regulatory supervision? Two, should antitrust law be more open to physician claims regarding anti-competitive effects on quality now that the medical profession is less likely to be able to abuse any power it is given?

\section{B. Assumption 2: Purchaser Actions are Pro-Competitive}

The traditional model of physician control described above located the medical profession at the fulcrum of health system transactions, responsible for providing or "ordering" all necessary goods and services for patients. By default, this placed third-party payers such as insurance companies squarely on the purchaser side of the procurement equation. Today, however, health care purchasing is seldom done so simply. Rather, an array of intermediate parties-not only physicians, but insurers, employers, governmental entities, and others-choose the services to be provided to patients and/or the price to be paid for them. The degree to which this transition has been recognized by courts has important economic and policy implications because, apart from rarely enforced prohibitions against monopsony, antitrust laws operate in practice to restrain sellers, not buyers.

43. See Jon Gabel, Ten Ways HMOs Have Changed During the 1990s, HeALTH AFF., May/June 1997, at 134,136-37. This phenomenon contains an aspect of linear quality competition as well. To the extent that physicians participating in restrictive HMO panels were perceived to be inferior, offering a broad network allowed managed care to claim that the best physicians would be available to subscribers. 
In FTC v. Indiana Federation of Dentists, for example, the Supreme Court confronted the question of who should be entrusted to act as the consumer's surrogate. $^{44}$ In assessing the competitive effects of the dentists' collective refusal to provide x-rays, the Court equated the demand of the insurer with that of the individual health care consumer. ${ }^{45}$ To the Court's credit, it recognized potential problems of incentive incompatibility and probed the factual situation to satisfy itself that treating insurers as patient agents was appropriate under the circumstances. $^{46}$

Until recently, antitrust courts typically allowed health insurers to stand in the shoes of individual patients and afforded them the deference antitrust law traditionally extends to consumers of goods and services. Most courts tended to assume the integrity of the agency relationship without analysis or concluded that agency failures involving insurers are not an antitrust problem-at least not one that physicians should be empowered to assert. When sitting on the First Circuit, for example, then-Judge Breyer authored an opinion upholding insurer surrogacy against a quality-based challenge by physicians. Kartell v. Blue Shield involved Blue Shield's ban on balance billing, a practice that required providers to accept the insurer's negotiated rate as payment in full-that is, not to seek additional payment directly from patients. ${ }^{47}$ Plaintiff physicians argued that the ban would chill innovation by preventing higher quality physicians from receiving higher rates of compensation. The court rejected this argument, holding that Blue Shield was empowered to act on behalf of its customers and could be trusted to make appropriate price-quality tradeoffs. ${ }^{48}$

Kartell went beyond Indiana Federation. Even though the court in Kartell assumed for the purpose of argument that Blue Shield possessed monopsony power vis-a-vis physicians, it proceeded to extend to Blue Shield the full latitude antitrust laws extend to "buyers," without addressing what implications the insurer's market power might have in the triangular relationship among patients, providers, and payers. ${ }^{49}$ The opinion states:

44. FTC v. Ind. Fed'n of Dentists, 476 U.S. 447 (1986).

45. Id. at 457 ("The fact remains that the dentists' customers (that is, the patients and their insurers) sought a particular service: cooperation with the insurers' pretreatment review through the forwarding of $x$-rays in conjunction with claims forms.").

46. Id. at 463 ("Insurers deciding what level of care to pay for are not themselves the recipients of those services, but it is by no means clear that they lack incentives to consider the welfare of the patient as well as the minimization of costs.").

47. Kartell v. Blue Shield, Inc., 749 F.2d 922, 924 (1st Cir. 1984).

48. Id. at 924 ("To find an unlawful restraint, one would have to look at Blue Shield as if it were a 'third force,' intervening in the market place in a manner that prevents willing buyers and sellers from independently coming together to strike price/quality bargains ... The persuasive power of the district court's analysis disappears, however, once one looks at Blue Shield, not as an inhibitory 'third force,' but as itself the purchaser of the doctors' services."); see also Ball Mem'l Hosp., Inc. v. Mutual Hosp. Ins., 784 F.2d 1325, 1334 (7th Cir. 1986); Pa. Dental Ass'n v. Med. Serv. Ass'n, 632 F. Supp. 653, 671 (N.D. Pa. 1986).

49. Kartell, 749 F.2d at 926. Monopsony power in a particular buyer's market need not imply market power in the seller's market. With Blue Shield, however, the same factors that would suggest the existence of monopsony power for physician services would also indicate some level of market power in the market for health insurance. By contrast, one can argue that a competitive insurance 
The short-and conclusive-answer to these arguments is that normally the choice of what to seek to buy and what to offer to pay is the buyer's. And, even if the buyer has monopoly power, an antitrust court (which might, in appropriate circumstances, restructure the market) will not interfere with the buyer's (non-predatory) determination of price. ${ }^{50}$

If recourse is to be had, the ruling continues, it is not to be found in litigation: "A legitimate buyer is entitled to use its market power to keep prices down. The claim that Blue Shield's price scheme is 'too rigid' because it ignores qualitative differences among physicians is properly addressed to Blue Shield or to a regulator, not to a court."

This assumption has come under increasing suspicion as the balance of power between insurers and physicians has shifted. One reason the Supreme Court gave in Indiana Federation for believing that insurers could be trusted to act on behalf of consumers was the competitive nature of the insurance market. ${ }^{52}$ The growth of managed care, and more importantly the consolidation of certain geographic markets to include only a handful of health plans, has reduced public confidence in the underlying competitiveness of insurance. ${ }^{53}$ Moreover, employers who sponsor coverage for their workforces either are not considered effective advocates for individual consumers, or have come to be seen as equally aggressive as insurers at cutting costs, particularly because selfinsured arrangements have proliferated in recent years. ${ }^{54}$ At the same time, physicians ironically may now be more attractive to reviewing courts as consumer surrogates because they seem to be less economically powerful than in earlier times. ${ }^{55}$

market was an important factor in the Supreme Court's willingness in Indiana Federation to accept the insurer as the consumer's surrogate.

50. Id. at 929 .

51. Id. Kartell really holds that physicians were the wrong plaintiffs to pursue such claims. An antitrust action against insurance companies would still be available if the insurance market were not behaving competitively. Furthermore, patients/consumers would be empowered to seek a broader range of antitrust remedies against insurers than would contracting physicians (although they may not have sufficient incentives to do so).

52. FTC v. Ind. Fed'n of Dentists, 476 U.S. 447, 463 (1986) ("[Insurers] are themselves in competition for the patronage of the patients.").

53. But see Blue Cross \& Blue Shield v. Marshfield Clinic, 65 F.3d 1406, 1411 (7th Cir. 1995) (holding that there is a single, competitive market for health care financing, not a separate market for HMO services that the defendant could monopolize).

54. It is still hotly contested whose money is in play when employers "give" their workers health insurance. Economists agree that compensation paid in the form of health coverage is simply not paid as cash wages, making it entirely the money of workers. However, many employers (and employees) see it instead as an input cost to the business comparable to rent or raw materials. If employers make decisions on that basis, however ill-informed, critics of employer surrogacy have a point. See MARK V. PAUly, HEALTH BENEFITS AT WORK 15-35 (1997) (describing interviews with employers).

55. But cf. Arizona v. Maricopa County Med. Soc'y, 457 U.S. 332, 339-40 (1982). The Maricopa decision can also be viewed through the lens of agency and distinguished from Indiana Federation on that basis. The defendant, Maricopa County Medical Society, prepared a fee schedule that individual physician members agreed to accept as maximum compensation for services provided to Societyapproved insurance plans. The Court observed: "Even if a fee schedule is therefore desirable, it is not necessary that the doctors do the price fixing." Id. at 352. 
A clear indication of this change is the treatment of most-favored-customer clauses in contracts between insurers and providers, which have come to be seen as surreptitious strategies by powerful insurers to foreclose competition in the insurance market, rather than as straightforward attempts to obtain lower prices for consumers. In Ocean State Physicians Health Plan v. Blue Cross ${ }^{56}$ decided in 1989, the First Circuit confidently regarded a most-favored-customer clause imposed on physicians by a health plan as beneficial to consumers, extending Kartell to hold that "a health insurer... like Blue Shield must be viewed 'as itself the purchaser of the doctors' services." ${ }^{57}$ By the mid-1990s, however, the First Circuit had become more skeptical about most-favored-customer clauses. In United States $v$. Delta Dental of Rhode Island, ${ }^{58}$ the court recognized that such a provision could be regarded as unlawful on two theories. First, although nominally put in place vertically by an insurer, the clauses might in fact serve to police a horizontal price-fixing cartel at the provider level. ${ }^{59}$ Second, and of greater concern to the court, the clauses might be used by an incumbent insurer with market power to erect a barrier to market entry because any provider considering offering a discount at the margin to a competing insurer would be forced to discount all of its inframarginal units as well. ${ }^{60}$ Either behavior would ultimately harm consumers.

\section{Assumption 3: Price and Quality Competition Work in Tandem}

The popular perception that competition through managed care threatens quality directly challenges another assumption of conventional antitrust economics: that markets with active competition over price and output will also compete effectively over quality. In defining antitrust liability, courts have made a conscious effort to make health care markets look and function more like other markets. Part of this agenda operates at an ideological level. Antitrust courts generally follow a paradigm where markets and competition are trusted to ensure consumer welfare in holistic fashion, including hard-to-measure quality, as well as more easily verified price and output. ${ }^{61}$ In keeping with this belief, medical antitrust cases demonstrate a tendency to evaluate all anti-

56. 883 F.2d 1101 (1st Cir. 1989).

57. Id. at 1111 (citing Kartell, 749 F.2d at 924) (emphasis added). The court even considered irrelevant any inquiry into whether the cost savings obtained through the contractual provision at issue would be passed on to consumers. Id. at 1111 n.11 ("In the present case, Ocean State alleges that Blue Cross never actually passed along its savings to subscribers. But nothing turns on whether Blue Cross in fact lowered its rates. The fact remains that achieving lower costs is a legitimate business justification under the antitrust laws.").

58. 943 F. Supp. 172 (D.R.I. 1996).

59. Id. at 177 n.5.

60. Id. at 177 .

61. The microeconomic focus of contemporary antitrust doctrine tends to assess anti- and procompetitive effects predominantly in terms of implications for price and output, even when such simple models seem forced or inappropriate given the facts of cases. In National Collegiate Athletic Ass' $n v$. Board of Regents, for example, the colleges' collective allocation of television broadcast rights was summarily condemned because it reduced the number of games that would be broadcast (output). 468 U.S. 85, 99, 101 (1984). In this process, quality as a dimension of competition is often marginalized. 
competitive conduct, even that clearly affecting quality, using simplistic price/output rhetoric. ${ }^{62}$ Although many courts acknowledge quality as an independent dimension of competition, ${ }^{63}$ they usually assert without substantial economic support that increased price competition will be associated with improved health care quality. ${ }^{64}$ In practice, this leads courts to assess the conduct of medical professionals in light of behavior predicted of market actors in traditional economic models. In FTC $v$. Indiana Federation of Dentists, for example, the collective refusal of dentists to provide copies of x-rays demanded by third-party payers was judged against a benchmark consisting of conduct the Court would expect of individually rational businesses in a competitive environment. Central to the Court's condemnation of the dentists' practice was the FTC's finding that, absent the collective agreement, individual dentists making independent decisions would have succumbed to market forces and complied with the x-ray demands of third party payers. ${ }^{65}$

The tendency of courts to believe that price competition would serve quality objectives equally well arguably was exaggerated by the odd history of nonprice competition in health care. The poster child for efficiency gains in medical markets-usually raised in the hospital merger context-has long been the elimination of redundant technology purchased by facilities during less competitive times as part of a "medical arms race." The Cold War image was intended to suggest that competition on technology, though clearly a component of quality, was not really competition but social perversion. This suggestion was reinforced by popular belief in the 1970s and 1980s that physicians, who were still paid on a generous fee-for-service basis, performed so many unnecessary procedures that true quality would improve if less were done to patients. It was a

62. In Hospital Corp. of America v. FTC, for example, Judge Posner explained the theory under which the Clayton Act condemned hospital mergers that would create high levels of concentration:

The reduction in the number of competitors is significant in assessing the competitive vitality of the Chattanooga hospital market... [B]oth the ability of the remaining firms to expand their output should the big four reduce their own output in order to raise the market price (and, by expanding, to offset the leading firms' restriction of their own output) and the ability of outsiders to come in and build completely new hospitals are reduced by Tennessee's certificate-of-need law.

807 F.2d 1381 (7th Cir. 1986) at 1387. In Ball Memorial Hospital v. Mutual Hospital Insurance, Inc., Judge Easterbrook, a fellow Chicago Schooler, described the meaning and implications of hospital market power in the following manner:

[The Hospitals] claim that the Blues have (and abused) 'market power,' the ability to raise price significantly higher than the competitive level by restricting output ... the Blues do not have the power to restrict output in the market or to raise price because they furnish a fungible product that other people can and do supply easily.

$I d$. at 1331 (citations omitted).

63. See, e.g., Sokol v. Akron Gen. Med. Ctr., No. 5:95CV1108, 1997 U.S. Dist. LEXIS 22078, at *29 (N.D. Ohio Sept. 30, 1997) ("An antitrust plaintiff must show that challenged conduct affected the price, quality or output of medical services available to consumers in the relevant market."). In Sokol, the plaintiff claimed an anti-competitive effect with respect to both the price and quality of cardiac care. $I d$. at $* 6$.

64. See, e.g., U.S. Healthcare, Inc. v. Healthsource, Inc., 986 F.2d 589, 599 (1st Cir. 1993) ("Competition remains an essential force in controlling costs and improving quality in health care.").

65. FTC v. Ind. Fed'n of Dentists, 476 U.S. 447, 452 (1985). 
small, if illogical, step to conclude that hospitals that proposed to merge in order to become better competitors would offer both lower prices (because of their lower costs) and higher quality. ${ }^{66}$

Not surprisingly, this assumption changed as managed care proliferated, physician influence declined, and price competition increased. Fear of poor quality due to service under-use quickly replaced fear of over-use, all the more so because for-profit corporations struck the public (probably incorrectly) as more likely to succeed in their cost-cutting strategies than physicians and nonprofit hospitals had been as "output maximizers." Although these fears may be overblown, quality did suffer in some respects as price competition improved. In particular, transitional dislocations and poorly calibrated adaptations by financially stressed providers took a toll. Moreover, price competition in health insurance markets is often based on risk, not actual care. ${ }^{67}$ Indiana Federation appears almost quaint in hindsight because of its assumption that reviewing dental films would improve both price and quality by avoiding unnecessary care. A similar case arising today would almost certainly be understood as more about price-quality tradeoffs and less about eliminating waste. ${ }^{68}$

In sum, these observations suggest that the application of antitrust law to health care, although potentially "Copernican" in its newfound willingness to scrutinize professional practices for economic harm to consumers, has remained mired in quite "Ptolemaic" assumptions about the centrality of physicians. Although one can view Goldfarb and similar cases as echoing growing social distrust of government and professional elites in the immediate post-Vietnam, post-Watergate era ${ }^{69}$ medical antitrust law arguably has been directed primarily

66. It was particularly illogical because high output, a supposed indicator of effective competition, itself became suspect as a competitive phenomenon. The alternative story, and in our opinion the better one, is that public and private reimbursement practices during that era kept hospital prices artificially high. As is typical in price-supported industries, some of the surplus was kept as additional profit, but much was dissipated in competition to provide non-price benefits to consumers. The reason that technology was so often the medium of such competition is a simple one: Physicians (not insurers or the patients themselves) determined where patients were admitted and so were the "consumers" hospitals were competing to serve. Physicians found it more convenient to work in (and, therefore, admit their patients to) hospitals that had all the latest technology.

67. See Wynand P.M.M. Van De Ven \& Randall P. Ellis, Risk Adjustment in Competitive Health Plan Markets, in 1A HANDBOOK OF HeAlTh ECONOMICS 755, 771-76 (Anthony J. Culyer \& Joseph P. Newhouse eds., 2000) (explaining selection in health insurance markets); $c f$. Patricia Neuman et al., Marketing HMOs to Medicare Beneficiaries, HEALTH AFF., July/Aug. 1998, at 132 (concluding that HMOs market selectively to healthy seniors).

68. Similarly, a point made in passing by the Court to the effect that the dentists' collusion "reduced output" by not providing the x-rays could be interpreted rather differently today. The physical x-ray is not an additional unit of output itself, but the information it embodies has independent value to consumers. The markets for information and for the underlying product or service are distinct. See Cal. Dental Ass'n v. FTC, 526 U.S. 756, 776-77 (1999) (noting that "the relevant output for antitrust purposes here is presumably not information or advertising, but dental services themselves").

69. From this perspective, the application of antitrust law to the professions parallels recent antiestablishment social movements such as environmentalism, feminism, and consumerism. See Marc A. Rodwin, Patient Accountability and Quality of Care: Lessons from Medical Consumerism and the Patients' Rights, Women's Health and Disability Rights Movements, 20 AM. J.L. \& MED. 147 (1994). It also evokes earlier populist reactions against professional dominance, such as the widespread repeal of 
at serving the narrow cost-containment objectives of corporate purchasers. Managed care itself, though nurtured by the social agenda of the 1960s and the notion of "health maintenance" as a preventive, cooperative alternative to the paternalism of private practice medicine, similarly was co-opted by the economic agenda of the 1970s-oil shocks, stagflation, and rapidly growing worker and retiree health costs in rust-belt industries. Consequently, medical antitrust law has focused less on promoting "consumer sovereignty" per se than on generating price competition while still relying on physician control to maintain quality at acceptable levels.

IV

\section{TOWARD A "COPERNICAN" THEORY}

Having set forth the observational basis for a "Copernican" reformation of health care policy, we are now poised to outline its main elements. Some of these are well recognized in the scholarly literature and have even been incorporated fitfully into legal doctrine, while others are our suggestions for "Keplerian" refinements of nonprice competition in health care as it is presently understood. Underlying a Copernican approach is the desire to construct an integrated competition policy for health care markets, that recognizes its multicentric nature. Antitrust law constitutes only one planet in the night sky, representing a single, albeit quite important, set of tools available to policy-makers. Therefore, a Copernican view requires both rethinking the application of antitrust principles in their traditional domain and revisualizing the relationship between antitrust law and other forms of public and self-regulationconnecting, for example, the federal government's position as chief antitrust enforcer to its role as the largest purchaser of health care services and the driving force behind most technological innovation. The objective is to cultivate an environment capable of generating not only effective levels of price competition, but also appropriate trade-offs between price and quality, as well as one able to accommodate other important social objectives, such as assuring broad access to care.

\section{A. Competition Policy at the Market-Regulatory Interface}

A weakness of Ptolemaic antitrust law is its tendency to artificially segregate private conduct from public conduct, separate market functions from government functions, and isolate quality as a professional or regulatory concern rather than a competitive one. Traditional antitrust law has a bias in favor of market-facilitating forms of intervention, and, as we will discuss shortly, a bias against market-displacing interventions, even if this division is difficult to rationalize from a strictly economic perspective. ${ }^{70}$ Furthermore, traditional anti-

professional licensing laws by Jacksonian Democrats in the 1820s and 1830s. See STARR, supra note 42, at $55-59$.

70. An antitrust standard framed in terms of enhancing competition can accommodate remedial measures for market failure that are market-facilitating more easily than those that are market- 
trust analysis is prone to consider markets as autonomous realities rather than as embedded in a broader social context and affected by a range of public policies and actions. Finally, antitrust law is apt to evaluate the desirability of private action in relation to a structural understanding of competition rather than its likely effects on total social welfare. In varying degrees, a Copernican view of antitrust challenges each of these strongly held assumptions.

From an economic perspective, whether competition will help or harm the quality of health care depends upon whether increases in quality can be translated into increases in profits. There are at least four different ways that quality and profits can be related. First are demand-side models in which increases in provider-specific quality either increase the price that providers can charge or the number of patients seeking services. Second, quality and profits can be related through the provider's production function. Given the degree of scientific uncertainty associated with many medical problems, organizational or technological innovation can create profit opportunities through the introduction of new forms of treatment or new systems of providing care. Third, quality and profits can be related, sometimes perversely, through various forms of risk selection. The patient population that a provider attracts will depend, among other things, on that provider's perceived quality, with persons with greater medical needs being disproportionately attracted to higher quality providers. When the provision of medical services is combined with the sale of insurance, therefore, profitability can be enhanced by attracting relatively lower risks, or diminished by attracting relatively higher risks, a problem that increased choice (though itself an attribute of quality) can exacerbate. Finally, certain forms of competition can destroy value because of health care's strong relational character. Specifically, medical trust may evaporate if consumers feel that health care is nothing more than a series of marketplace decisions. This last consideration is not as remote from marketplace processes as it may seem; trust and other hard-to-quantify social factors are necessary for private markets to be viable institutions in the first place.

Any set of antitrust (or regulatory) tools applied to health care markets therefore must be robust enough to address the effects of a wide range of market failures. Although market failures have been observed in health care for decades, ${ }^{71}$ courts have not always taken them into account when performing

displacing. Market-facilitating remedies address imperfect markets by helping them operate more effectively. The end result, however, is merely a market that looks and acts the way we think markets ought to look and act. Information disclosure, certification, the collective bargaining for, and monitoring of copyrighted works in Broadcast Music, Inc. v. Columbia Broadcasting System, Inc., 441 U.S. 1 (1979), and the rules prohibiting night trading in Chicago Board of Trade v. United States, 246 U.S. 231, 238 (1918), can be thought of as market-facilitating measures. By contrast, market-displacing measures work to counteract market failure through means and mechanisms that may be quite nonmarket in their appearance and operation, potentially sidestepping competition entirely to achieve greater efficiency. Defining efficiency according to some form of total welfare standard would be necessary to fully embrace market-displacing measures. care).

71. See Arrow, supra note 35 (discussing imperfections that impair the marketability of health 
antitrust analysis. In Jefferson Parish Hospital v. Hyde, ${ }^{72}$ for example, the Supreme Court required the plaintiffs to plead and prove the existence of market power in order to establish a prima facie case of per se illegal tying, but was unreceptive to the argument that market failures endemic to medical markets made it possible for parties to have and exercise "market power" with market shares substantially lower than in other industries. ${ }^{73}$ Similarly, in Indiana Federation, the Court implicitly embraced a very optimistic set of beliefs about the ability of health care markets to work effectively. The Court assessed the legality of the dentists' conduct in light of whether it was consistent with individually rational behavior by competitors, not whether collective action might improve market function. ${ }^{74}$ To be fair, the collective action at issue was relatively easy to condemn, and the Court displayed sensitivity to at least one type of market failure. In a market already plagued with information asymmetries, the dentists' collective refusal to provide information specifically demanded by sophisticated buyers was hardly likely to improve competition.

Significantly, the Supreme Court's 1999 decision in California Dental Ass'n v. $F T C,{ }^{75}$ which upheld various collective restrictions on dental advertising imposed by a professional association, expressly considered the legality of the alleged restraint in light of market failures endemic in health care markets. Furthermore, the Court treated the extent of market failure and the competitive effects of particular conduct as empirical questions. ${ }^{76}$ While the case signals greater judicial sensitivity to market failure, including its nonprice consequences, it also suggests the dangers that such an inquiry might entail. Specifically, more nuanced market failure analysis can be used as a pretext to rationalize a variety of otherwise anti-competitive restraints. Indeed, for the first time in decades, the Court cited Goldfarb's footnote 17 in a manner that could plausibly be read to usher back the era of pre-Goldfarb professional control. ${ }^{77}$

We do not believe that this is the only or best reading of California Dental Association. A return to professional dominance is not a necessary consequence of taking market failure seriously. The Court's citation to Goldfarb's footnote 17 neither suggests that the professions are immune from antitrust scrutiny, nor that different antitrust standards would be applied to their conduct. $^{78}$ The opinion does reflect, however, the Court's belief that professional

72. 466 U.S. 2 (1984).

73. Specifically, the plaintiff noted that "the prevalence of third-party payment for health care costs reduces price competition, and a lack of adequate information renders consumers unable to evaluate the quality of the medical care provided by competing hospitals." Id. at 27 ("While these factors may generate 'market power' in some abstract sense, they do not generate the kind of market power that justifies condemnation of tying.").

74. Ind. Fed'n, 476 U.S. 447, 456.

75. 526 U.S. 756, 780-81 (1999).

76. $I d$. at $786-88$.

77. Id. at 773 n.10 (quoting Goldfarb's footnote 17).

78. The citation to Goldfarb's footnote 17 came in the context of the Court's discussion of economic market failures. The sentence preceding the Court's footnote citation is as follows: "The restrictions on both discount and nondiscount advertising are, at least on their face, designed to avoid 
markets are associated with particular failures that should influence the economic, and hence, legal, evaluation of alleged restraints of trade.

We are certainly not the first to connect market failure to competition and quality in health care. Indeed, as already noted, a "market failure defense" has long been a staple of antitrust scholarship, both generally and as applied to health care. ${ }^{79}$ Over a decade ago, Thomas Greaney systematically assessed the potential for market failure analysis to enhance quality competition in health care. ${ }^{80}$ Greaney reviewed a series of actual and potential failures afflicting health care markets: information problems, seller heterogeneity and imperfect mobility, monopoly practices, natural monopolies and externalities, public goods, and insurance markets. ${ }^{81}$ He concluded that a narrow market failure defense could benefit consumers by allowing physicians collectively to establish quality standards and provide structured information to patients, but that courts should exercise caution for fear of straying too far from the economic justifications for antitrust law and enmeshing themselves in situation-specific balancing tests that could not be resolved on a principled basis. ${ }^{82}$

Our historical sense of the issues facing the health care system when Greaney wrote supports his prescription. Nonetheless, at the same time, there have been significant shifts in the cause and nature of health care market failures since Greaney's contributions. In the late 1980s, competition of any kind in health care was still a novelty, and physicians indisputably controlled both the quality and cost of care. Accordingly, Greaney's market failure proposal aimed to encourage physicians to point out quality trade-offs inherent in price competition without permitting physicians to avoid both price and quality competition by articulating quality concerns that would trump competitive considerations entirely. In other words, the default position for the health care system was still non-competitive, and the major reason to identify a narrow market failure defense for quality-related conduct was to prevent quality from acting as a brake on overall competition.

By contrast, today's health care system is viciously price-competitive, and both cost and quality are significantly influenced by parties other than physi-

false or deceptive advertising in a market characterized by striking disparities between the information available to the professional and the patient." Id. at 772. Following the footnote, the Court cites a number of scholarly works analyzing information market failures, including Akerlof's seminal contribution. See George A. Akerlof, The Market for "Lemons": Quality Uncertainty and the Market Mechanism, 84 Q. J. ECON. 488 (1970).

79. See Philip E. Areeda \& Herbert Hovenkamp, Antitrust law: An Analysis of ANTITRUST PRINCIPLES AND THEIR APPLICATION II 1504 (2000) (discussing market failure defenses generally).

80. Greaney, Quality of Care, supra note 6 (endorsing a narrow market failure defense in health care); see also Clark C. Havighurst, Doctors and Hospitals: An Antitrust Perspective on Traditional Relationships, 1984 DUKE L.J. 1071, 1095-96 (1984) (noting that market failures in health care create limited opportunities for pro-competitive collective action); Clark C. Havighurst \& Nancy M.P. King, Private Credentialing of Health Care Personnel: An Antitrust Perspective (Part Two), 9 AM. J.L. \& MED. 263, 296-98 (1983) (same); Kauper, supra note 32 (discussing the effects of market failure).

81. See Greaney, Quality of Care, supra note 6, at 633-40.

82. Id. at 664-65. 
cians. Quality remains central to health care but, as our empirical study shows, is often regarded non-competitively and therefore ignored by courts attempting to oversee the competitive marketplace. ${ }^{83}$ In other words, the default position for today's health care market is price competition, and our purpose in discussing market failure is to validate quality explicitly as a competitive dimension rather than merely a professional concern. Furthermore, a critical part of this endeavor is to evaluate the role of non-physician actors in fostering or impeding quality competition.

At the same time, the dramatic changes that have occurred in health care markets over the past fifteen years should give us pause. Medical market failures are inconstant and multidimensional. To the extent that antitrust courts have attempted to address market failures, it has been primarily in the limited domain of imperfect information and the relatively safe confines of demandside models of competition. There is good reason to ask whether a more expansive view of antitrust law is simply an invitation for courts to sail rudderless on a sea of doubt. There is no simple taxonomy categorizing the various market failures plaguing health care markets or identifying their appropriate remedies. Copernican analysis of medical market failure is likely to call for more complicated economic models and greater sensitivity to dynamic and not simply static efficiency concerns.

Many of these tensions are illustrated by Clark Havighurst's recent exposition of antitrust law's impact on the market failures identified in Arrow's seminal 1963 article on medical economics. ${ }^{84}$ Arrow's principal thesis was that nonmarket institutions such as physicians' ethical codes and non-profit hospitals serve to fill "optimality gaps" that would otherwise cripple markets beset by uncertainty and asymmetric information. Arrow's analysis, however, is ambiguous in an essential respect: He never specifies whether the activities of these non-market institutions constitute primarily market or non-market behavior. ${ }^{85}$ A potential explanation for this failure to specify roles is that Arrow regarded the physician's position in health care as far more central than it is today, and perhaps even more central than was the case when his analysis was published. ${ }^{86}$ One might speculate that Arrow hesitated to assign commercial motivations to physicians because the mythos of physician virtue was so strong, and its history so sustained. Alternatively, whether the "gap-filling" institutions were predominantly market-facilitating or market-displacing may not have been

83. See Hammer \& Sage, supra note 7, at 617-20.

84. See Havighurst, supra note 29.

85. Arrow, supra note 35, at 947 ("I am arguing here that in some circumstances other social institutions will step in to the optimality gap."); see also Peter J. Hammer, Arrow's Analysis of Social Institutions: Entering the Marketplace with Giving Hands?, 26 J. HEALTH POL. POL'Y \& L. 1081 (2001) (discussing Arrow's understanding of market and non-market institutions).

86. See Peter J. Hammer et al., Kenneth Arrow and the Changing Economics of Health Care: "Why Arrow? Why Now?”, 26 J. HEALTH POL. POL'Y \& L. 835, 844-45 (2001). For example, Arrow devotes virtually no attention in his article to pharmaceuticals or to technologic innovation. 
as important a distinction to Arrow, an economist, as it would have been for an antitrust scholar.

When the non-market institutions are, by accident or design, also market participants, however, the distinction can be central for antitrust purposes. Havighurst argues that professional activities that might otherwise be potential restraints on trade should be evaluated under a "market failure" approach if those interventions make markets work more smoothly. ${ }^{87} \mathrm{He}$ is less sympathetic to potential restraints of trade that displace, rather than simply facilitate, market operation. Part of his concern is a legitimate fear that a variety of worthy purposes might be invoked to justify market distortions, leading courts to stray from the focus contemporary antitrust law maintains on strictly economic considerations. Another part of his concern reflects a traditional bias in antitrust analysis toward assessing the effects, and therefore, the desirability, of restraints in terms of their structural effects on competition. This bias tends to foreclose a range of Arrovian market-displacing institutional responses to market failures that may well be welfare-enhancing even in strict economic terms.

A Copernican view would challenge these limitations with respect to market failure. As opponents of managed care intuit, but rarely articulate with precision, a competitive health care system not dominated by the medical profession may require special attention from government to safeguard values that were previously protected through professional mechanisms that are no longer viable. Accordingly, a Copernican approach would consider several collective action problems in health care, including charity, improvements in medical knowledge, and the maintenance of therapeutic trust, as potentially amenable to incorporation into an integrated competition policy.

Another argument in favor of expanding the express purview of antitrust is that, whether or not one espouses a Copernican view in theory, courts will not be able to avoid more complicated forms of market failure analysis in practice. For example, the market failure defense outlined in California Dental will force courts to make detailed factual inquiries into the competitive implications of self-regulatory activities. ${ }^{88}$ Because antitrust law generally condemns efforts by private parties to use market power to define and enforce their own conception of sound public policy, ${ }^{89}$ this will inevitably produce controversy-especially if self-regulatory bodies are permitted to discipline violators rather than merely deny voluntary accreditation or some other informational imprimatur. Among other things, antitrust law will need to strengthen its ability to distinguish "real" from "sham" self-regulation. Potential abuses can be curbed both through substantive criteria defining antitrust liability and prophylactic procedural

87. Havighurst, supra note 29 , at $946-49$.

88. Id. at $949-53$.

89. See, e.g., Fashion Originators' Guild of Am. v. FTC, 312 U.S. 457, 468 (1941) (holding illegal a collective refusal by dress manufacturers to deal with retailers that sold unauthorized copies). The case most deferential to self-policing, Silver v. New York Stock Exchange, involved an implied statutory exemption from antitrust liability conferred by the federal securities laws. 373 U.S. 341 (1963). 
requirements. In those instances where the exercise of private economic power is not condemned outright, it can be "regulated" through common law antitrust rules not substantially different from those used to ensure public due process, transparency, and good governance in administrative procedure acts. ${ }^{90}$ This analogy also suggests that antitrust law can have something constructive to say about the competitive implications of explicitly governmental processes.

In addition to distinguishing between legitimate and pretextual market failure defenses, and adopting appropriate standards to police the conduct of potentially market-displacing social institutions, antitrust courts must determine what decision rule will guide their analysis. A fundamental question is whether market failure is perceived as a problem of competition or of efficiency. In conventional rule of reason analysis under the antitrust laws, the terms attached to the judicial inquiry_-"procompetitive effects," "efficiencies," "anti-competitive effects"-mix concepts that are intellectually distinct. Efficiency refers to the maximization of social needs given social resources, and can be defined by welfare economics in various ways. Competition refers to a set of industrial structures and processes that favor active, informed bargaining between buyers and sellers. The two notions sometimes converge in an empirical, microeconomic sense as the area between the demand and supply curves representing consumer surplus, but they do not necessarily mean the same thing.

One's answer to this question determines whether a market failure defense should be limited to specific remedies for identifiable market imperfections, such as lack of information or misaligned incentives between consumers and purchasing intermediaries, or whether it extends to second-best justifications for anti-competitive conduct in light of market failure. ${ }^{91}$ The latter approach necessitates a total social welfare metric of efficiency, which sums consumer and producer surplus rather than equating efficiency with consumer benefit, as is conventional in antitrust analysis. ${ }^{92}$ With respect to quality, one can argue that a legitimate market failure defense to an allegation of anti-competitive conduct should demonstrate that consumers obtained better value (price per unit quality) than otherwise would have been the case. Because producers would not engage in these activities unless they too benefited, one can regard a focus on competition and consumer surplus in market failure analysis as fostering Pareto

90. See Allied Tube \& Conduit Corp. v. Indian Head, Inc., 486 U.S. 492 (1988) (discussing processoriented standards that would tend to make the actions of private standard-setting organizations "procompetitive" under antitrust rule of reason analysis). But see Northwest Wholesale Stationers v. Pac. Stationery \& Printing Co., 472 U.S. 284, 293 (1985) ("[T]he antitrust laws do not themselves impose on joint ventures a requirement of due process.").

91. A classic example of this "two wrongs make a right" approach is the proposition that monopoly power for health care providers is welfare-enhancing because the output restriction it theoretically produces serves to counterbalance the moral hazard that leads insured consumers to overuse health services. See Martin Gaynor et al., Are Invisible Hands Good Hands? Moral Hazard, Competition, and the Second Best in Health Care Markets, 108 J. POL. ECON. 992 (2000) (concluding that competitive insurance markets would dissipate any such effect).

92. See Peter J. Hammer, Antitrust Beyond Competition: Market Failures, Total Welfare, and the Challenge of Intramarket Second-Best Tradeoffs, 98 MICH. L. REV. 849, 876-79 (2000). 
improvements that would be voluntarily embraced by all concerned. By contrast, a total social welfare criterion, standing alone, suggests Kaldor-Hicks efficiency analysis, which does not seem as well suited to governing voluntary market transactions. Nonetheless, viewing market failure in health care through a wider efficiency lens may have tremendous advantages in light of the fact that a system no longer dominated by physicians may still have good reasons to pursue goals traditionally associated with medical ethics and medical professionalism, some of which mainly affect individual "transactional" encounters between patients and the health care system, while others of which play larger social roles. In this section of the article, we discuss market failures and the Copernican health care system without binding ourselves to a position on the general question of competition or efficiency. ${ }^{93}$ We consider the controversial implications of a total social welfare approach to market failure, which involve the medical production function and the distribution as well as the allocation of medical services, in the last section of the article.

\section{B. Traditional Market Failures and Copernican Competition Policy}

What makes our approach to market failure deserving of the Copernican metaphor? For one, we address the specific implications of power dispersionthe physician-centered health care system becoming a multicentric system. Previous work on market failures and antitrust analysis in health care has emphasized the risk of perpetuating physician control, which is arguably no longer the operative consideration. In addition, we take advantage of our shifting frame of reference to examine the relationship between market failure and quality as a coherent competitive limitation. We do not claim to provide a definitive assessment of market failures in a Copernican setting, but rather intend our analysis to elucidate a range of considerations that are relevant to such an inquiry.

1. Agency.

A Copernican view of health care markets has its greatest impact on market failure analysis in its understanding of how buyers and sellers transact their business. The Ptolemaic interpretation of health care purchasing is dyadic: The patient negotiates with the physician. Like its astronomical analogy, this interpretation has admitted various refinements. The modern patient is typically armed with health insurance as well as cash. The physician no longer provides most services directly, but procures (orders) them or refers the patient to other physicians who can. The physician is also subject to various ethical and legal

93. More pragmatically, one can envision embracing different decision rules (competition versus efficiency) based on the institutional competencies of the actors involved in setting competition policy. This may argue in favor of a simpler competition-focused decision rule for courts evaluating potentially market-facilitating behavior in antitrust cases, while channeling more complicated market-displacing measures through legislative or administrative processes where a total welfare standard of efficiency could be employed, or where the decision-maker might consider a broader range of non-economic social objectives. 
constraints on exploitation and incompetence. Still, once one admits that the transaction is economic and not altruistic in character, the patient is indisputably the buyer and the physician the seller. Under these assumptions, a market failure defense in health care largely reduces to the question whether particular collective activity or structural features tend to increase or decrease competition among physicians for patients.

Viewing the health care system in multicentric terms requires a sharp departure from this analysis. Not only do many services that patients receive involve sophisticated industrial or team production that belies the centrality of the physician's role, but "purchasing" and "selling" have become functions of several parties whose responsibilities with respect to patients interact with one another in complicated ways. As Lawrence Casalino observes, principal-agent relationships in contemporary health care involve health plans, employer and public sponsors, medical groups and network contracting organizations, private accrediting bodies, and government regulators. ${ }^{94}$ These intermediaries did not form overnight, but only recently has their activity become intense enough to be unintelligible using a simplified, Ptolemaic approach to the competitive effects of market failure.

Some low-hanging fruit relates to the role of hospitals in the production of health care. Our empirical study revealed that physicians continue to bring antitrust claims against hospital medical staffs that deny or restrict practice privileges, notwithstanding very low plaintiff success rates and the existence of explicit immunity under federal law. ${ }^{95}$ The salience of these suits depends to some degree on the continued belief that the individual physician is the relevant competitor, rather than conferring that designation on sellers of an assemblage of professional and technical skills such as modern hospitals. If antitrust doctrine made it clearer that staff privileges determinations in today's competitive environment are presumed to be actions taken by hospitals specifically to improve their ability to compete on quality against other hospitals, and not actions taken by fellow physicians to protect quality in some vague professional or social sense that might be perverted to anti-competitive ends, these cases might finally go away, conserving valuable judicial resources.

Further evidence that antitrust courts are struggling to determine which plaintiffs or defendants represent individual consumer interests (and, conversely, which are mere sellers) comes from cases involving the contracting practices of health plans. The Ptolemaic premise of a dyadic market placed insurers squarely on the buyer side of health care transactions and paid little attention to ways in which their incentives and those of individual consumers

94. Lawrence Casalino, Managing Uncertainty: Intermediate Organizations as Triple Agents, $26 \mathrm{~J}$. HeALTH POL. POL'Y \& L. 1055, 1055-57 (2001).

95. Hammer \& Sage, supra note 7, at 568-70 (showing that staff-privileges cases declined significantly from 1985-1989 to 1995-1999 but constituted approximately one-third of medical antitrust litigation even in the more recent time period); Health Care Quality Improvement Act of 1986, Pub. L. No. 99-660, 100 Stat. 3784 (codified as amended 42 U.S.C. $\S \S 11101-11152$ ) (2000) (granting antitrust immunity to medical staff admission processes that meet certain standards). 
and patients might diverge. ${ }^{96}$ For antitrust purposes, physicians traditionally were disempowered from questioning the actions of payers. Managed care may lead courts to reassess this position to some degree, with physicians-long the targets of antitrust enforcement-somewhat ironically being rehabilitated as patients' economic as well as clinical agents, while the claims of other parties as putative consumer representatives are subjected to closer scrutiny.

This has not yet occurred. Ambroze v. Aetna Health Plans illustrates the extension to managed care markets of the traditional designation of payers as consumer-surrogates. ${ }^{97}$ In Ambroze, physician anesthesiologists challenged aspects of their managed care contract that they argued interfered with their ability to provide quality care to their patients, in essence asking the court to decide, for antitrust purposes, who the proper agent was for the patient. The court rejected the plaintiffs' argument, reasoning that the managed care company was properly making price and quality decisions on behalf of patients. ${ }^{98}$ Courts that are more skeptical of managed care frequently engage in rhetoric rather than detailed analysis of agency relationships. In Blue Cross \& Blue Shield v. Marshfield Clinic, for example, Judge Posner expressed his doubts that managed care mirrors patients' preferences regarding quality in memorable but imprecise terms: "[T]he HMO's incentive is to keep you healthy if it can, but if you get very sick ... to let you die as quickly and cheaply as possible."'"9 In FTC v. Butterworth Health Corp., the court took a different approach, regarding managed care organizations as preferential purchasers who spoke only for a subset of potential customers in the market. ${ }^{100}$ To some extent, of course, antitrust law for procedural reasons is not well suited to perform discriminating evaluations of "agency market failure." Specifically, antitrust law makes it difficult to challenge actions by intermediaries because it imposes strict requirements of standing and antitrust injury on would-be plaintiffs, and limits damage actions to those who purchased directly from the defendant. ${ }^{101}$

96. For example, when insurers contract for medical services on behalf of insureds, they may fail to arrange for services that correspond to the preferences of the insureds, or they may act opportunistically (stinting) at the time when services are called for under the contract.

97. No. 95 Civ. 6631, 1996 U.S. Dist. LEXIS 7274 (S.D.N.Y. May 28, 1996).

98. The court held that the alignment of patient and payer interests should be left in the first instance to the economic exchange between them, and if that market was incapable of safeguarding the patient's interest, then through recourse to regulators or legislators. Ambroze, 1996 U.S. Dist. LEXIS 7274 at $* 21-22$ (citing Kartell, 799 F.2d 922).

99. 65 F.3d 1406, 1410 (7th Cir. 1995).

100. 946 F. Supp. 1285, 1299 (W.D. Mich. 1996) ("Viewing the managed care discounts in light of their impact on the welfare of consumers as a whole exposes them as illusory. Such selective price advantages are hardly the sort of benefit the antitrust laws are designed to protect.").

101. See E. ThOMAs Sullivan \& JeFFrey R. HARRISON, UNDERSTANDING ANTITRUST LAW AND ITS ECONOMIC IMPLICATIONS 38-56 (3d ed. 1998). At the same time, some courts have demonstrated a willingness to think creatively about questions of standing in the context of managed care contracting. See, e.g., In re Brand Name Prescription Drugs Antitrust Litig., 123 F.3d 599, 606 (7th Cir. 1997) (invoking an exception to Illinois Brick's indirect purchaser bar where the complaint alleged that the intermediate purchasers, wholesale drug middlemen, were also alleged conspirators); Rozema v. Marshfield Clinic, 977 F. Supp. 1362, 1375 (W.D. Wis. 1997) (rejecting defendant's argument that 
Furthermore, a Copernican perspective forces us to confront the possibility that the question of which parties represent consumers is an incoherent one. Historical convention and public policy instinct both tend to reinforce the perception that an individual with medical needs is the true consumer of health care and that all other entities or groups exist to ensure that such an individual can obtain care on competitive terms. It was easy to maintain this view when insurers, employers, and government sponsors stood on the sidelines of markets for medical services, but it is harder now that they are active players. Now, one must ask whether purchasing is done not on behalf of individual patients but for these organizations' own accounts, or for collective interests that the organizations at some level serve. For example, ethicists and policy-makers continue to debate the appropriateness of orienting physicians to serving "populations," such as the aggregate membership of a managed care plan, rather than individuals. $^{102}$ Contractual and regulatory obligations will point to the real party in interest much of the time, but many areas remain where the interpretation of those duties is unsettled..$^{103}$

On the other hand, sensitivity to the proliferation of intermediaries in managed care, and to the different roles that physicians now play, could help courts assess the competitive implications of particular situations. Certainly, absent evidence that insurers' demands reflect the underlying preferences of consumers and therefore can be attributed to them as buyers, there seems no reason to excuse the exercise of market power-either collusive or monopolistic - when such demands are made. There even may be occasional instances where physicians undertake such strict patient advocacy responsibilities that they, rather than insurers, should properly be regarded as buyers' agents. In making these determinations, antitrust courts will need to take account of the regulatory environment as well as the details of contractual relationships. In addition, improved awareness of agency failures might allow courts to reject antitrust challenges to self-regulatory activities that reduce the cost of monitoring intermediaries, such as prohibitions on conflicts of interest involving employers and insurers, or standards for making insurance coverage decisions.

2. Asymmetric Information.

It has become a truism that health care is beset by significant informational asymmetries between physicians and patients. ${ }^{104}$ Informational failures deter

HMO subscribers were disqualified as plaintiffs because they were indirect purchasers of physician services that were being "resold" through the HMO).

102. See, e.g., Jerome P. Kassirer, Managing Care: Should We Adopt a New Ethic?, 339 New ENG. J. MED. 397, 397-98 (1998) (criticizing a population-based approach to medical ethics).

103. For example, the technical fact that fiduciary duties in employee benefit plans run to the plan as a whole, not to individual beneficiaries, has yet to find clear application with respect to health coverage under ERISA. See William M. Sage, UR Here: The Supreme Court's Guide for Managed Care, HeAlth AFF., Sept./Oct. 2000, at 219, 221-22.

104. Many health care services are what economists call credence goods, meaning that consumers cannot necessarily assess their quality even after consuming them. See Arrow, supra note 35, at 951-52 (identifying asymmetric information between physician and patient as the principal obstacle to market functioning in health care). On the other hand, many markets function acceptably despite information 
both price and nonprice competition. As Justice Breyer stated in dissent to California Dental Ass'n, for price competition to be effective, consumers must be able to learn about lower prices and make purchasing decisions that reward low-price providers. ${ }^{105}$ Similarly, effective quality competition requires identifying relevant differences along quality dimensions and credibly communicating those differences to quality-sensitive buyers of health care services. ${ }^{106}$ Medical antitrust law, however, traditionally viewed informational asymmetries as unavoidable and intractable,$^{107}$ and therefore regarded with suspicion assertions by physician-sellers that seemingly anti-competitive conduct was merely an attempt to improve consumer information. ${ }^{108}$

By contrast, a market failure analysis would approve pro-competitive efforts to reduce information asymmetries, even if the mechanism for doing so involved otherwise suspect collective activity. ${ }^{109}$ Conceptually, information market failures are relatively easy to accommodate as a matter of antitrust doctrine. The fundamental heuristic is that additional information will make the market operate more efficiently. Consequently, agreements that restrict the type of information available to the market would be treated skeptically by antitrust courts, ${ }^{110}$ while the law would stretch to permit forms of cooperation that increased the quantity or quality of information available to the market, such as accreditation and professional credentialing.

asymmetries, raising the possibility that it is society's unwillingness to let people make their own mistakes where health care is concerned, and not any special degree of consumer ignorance, that lies behind various regulatory requirements. See James C. Robinson, The End of Asymmetric Information, 26 J. HeALTH POL. POL'Y \& L. 1045, 1046-49 (2001).

105. Cal. Dental Ass'n v. FTC, 526 U.S. 756, 784 (1999) (Breyer, J., dissenting).

106. Id.

107. See, e.g., Del. Health Care v. MCD Holding Co., 957 F. Supp. 535, 543 (D. Del. 1997).

Patients generally do not have the sort of information necessary to make informed judgments about what medical procedures are appropriate, which hospital is best able to provide them, or what they will cost. It is often difficult and expensive for them to search for this sort of information, and they are unlikely to be in a position to evaluate the information they do Id. receive.

108. For example, the AMA justified its collective refusal to associate with "unscientific cultists" (for example, chiropractors) on the grounds that a joint commitment to scientifically valid treatment was necessary to assure consumers that physicians competing with one another could be trusted to offer services of sufficient quality. See Wilk v. AMA, 895 F.2d 352, 361 (7th Cir. 1990) (rejecting this argument).

109. Because self-regulation sits at the interface between public and private activity, it is worth noting that potential antitrust liability for private parties can be matched by constitutional constraints on limiting speech when public parties are involved. For example, a dispute over the constitutionality of provisions in the FDA Modernization Act restricting tobacco advertising was recently decided by the Supreme Court. Western States Med. Ctr. v. Shalala, 238 F.3d 1090 (9th Cir. 2001), aff'd sub nom. Thompson v. Western States Med. Ctr., 122 S. Ct. 1497 (2002) (holding that certain restrictions on drug advertising contained in the Food and Drug Administration Modernization Act of 1997 violate the First Amendment).

110. In this regard, for example, dentists' refusal to provide x-ray support for their treatment recommendations in Indiana Federation violates antitrust law because it represents a collective decision among competitors to perpetuate informational asymmetry between buyers and sellers. 
Cases limiting information exchange supposedly to further competitive objectives present closer questions. As recognized in California Dental Ass'n, some information can be disruptive to markets. ${ }^{111}$ If information is unreliable, unaided consumers may have a difficult time assessing competing quality claims, creating the possibility that privately imposed restrictions on false or misleading information could have pro-competitive effects. ${ }^{112}$ Nevertheless, existing demand-side models provide a fairly workable framework in which to assess the consequences of imperfect information and to predict the likely effects of information-related restraints.

How does a Copernican view of health care alter this approach to information market failure? First, many of the parties that use information in a quasipurchasing role in a multicentric health care system are more sophisticated than individual consumers. Employers, health plans, government payers, and the like need far less protection from false or misleading information, so collective efforts to restrict the flow of false information will rarely, if ever, enhance competition. This provides an explanation of the different results in Indiana Federation and California Dental Ass'n. In the former case, information (x-rays) establishing the medical basis for dental work was requested by insurance companies with the ability and incentive to hire experts who could interpret it. ${ }^{113}$ By contrast, California Dental Ass'n involved a situation in which Ptolemaic analysis led to an acceptable resolution: The information at issue in the case was being provided mainly by solo-practice dentists serving individual patients on a cash basis or in connection with relatively unmanaged dental insurance, and therefore arguably had less competitive value than it presented risk of deception. ${ }^{114}$

Second, our empirical findings with respect to antitrust litigation suggest that antitrust courts typically factor quality into the equation only in vague, general terms. Quality measurement systems that have been developed by health services researchers, and even those specifically designed to assist employers' selection of health plans for sponsorship, are still under-used. Because it seems well within the capabilities of both institutional purchasers and appropriately guided individual consumers to make use of this data, the problem may be one either of buyer inertia or suboptimal design. A market failure defense therefore should be particularly sensitive to sellers' collective efforts either to standardize or monitor the release of performance or outcome data to consumers. Along the same lines, antitrust law should hesitate to

111. Cal. Dental Ass'n, 526 U.S. at 771 n.9 ("That false and misleading advertising has an anticompetitive effect, as that term is customarily used, has been long established.").

112. Id. at 775, 777-78.

113. FTC v. Ind. Fed'n of Dentists, 476 U.S. 447, 455 (1986).

114. Cal. Dental Ass'n, 526 U.S. at 772 (citing Hayne E. Leland, Quacks, Lemons, and Licensing: A Theory of Minimum Quality Standards, 87 J. POL. ECON. 1328, 1330 (1979); B. FURROW ET AL., 1 HEALTH LAW § 3-1, 86 (1995) (describing the common view that "the lay public is incapable of adequately evaluating the quality of medical services"). 
penalize competitors who can establish superior quality, as it can do inadvertently by considering them monopolistic markets unto themselves. ${ }^{115}$

Third, the increased diversity and sophistication of both purchaser and seller institutions, and the proliferation of agency relationships among them, argue for shifting away from minimum quality standards enforced through mandatory licensure, and toward voluntary informational criteria. It is well-established that licensing implicitly denies consumers a range of choices and alternatives that might otherwise be available, often at lower prices. ${ }^{116}$ Licensing also has serious limitations as a quality-control device. A one-time assurance of competence is of limited value when the underlying science and technology change dramatically over the course of a medical career. Licenses are seldom revoked or suspended, even in light of affirmative evidence of professional incompetence. Medical markets are reaching a level of maturity where a combination of information strategies-accreditation, title protection (regulating the right to use a title such as Dr.), certification, credentialing, and informed consumer choice-can assume the lead in ensuring quality, while at the same time improving efficiency in the technical provision of medical services. ${ }^{117}$

Fourth, the agency market failures referenced above suggest that information regarding agent competence and loyalty is more important in a Copernican health care system than in its physician-centered predecessor. ${ }^{118}$ Compromised agents have both psychic and pecuniary reasons for concealing conflicts of interest, especially if collective restrictions on disclosure prevent "unraveling" by keeping principal parties too ignorant of the risks to draw adverse inferences from non-disclosure. For that reason, prohibitions on revealing conflicts of interest, even for supposedly competitive (and therapeutic) objectives such as maintaining trust, should bear a heavy burden of proof. An imperfect example

115. For example, the "anchor hospital" theory put forward by the government but rejected by the district court in United States v. Long Island Jewish Med. Ctr., would have put the defendant hospitals' merger in jeopardy basically because the combined entity was significantly better than its local competitors. 983 F. Supp. 121 (E.D.N.Y. 1997). In Blue Cross \& Blue Shield v. Marshfield Clinic, the court accepted the characterization of the defendant medical clinic as so much better than the alternatives as to constitute a separate market, but nonetheless excused it as a natural monopoly. 65 F.3d 1406, 1412 (7th Cir. 1995).

116. $C f$. Arrow, supra note 35, at 953 (discussing professional licensure as limiting price-quality tradeoffs in medical care, and proposing alternatives). In addition to these demand-side considerations, licenses restrict entry and create significant rigidities in defining the production function for health care. Moving away from licensing and toward information strategies will not only improve the functioning of demand-driven incentives to provide appropriate levels of quality, it will also introduce incentives and flexibility on the supply-side of medical services that could permit more rational substitution of inputs and greater cost-effectiveness.

117. See William M. Sage \& Linda H. Aiken, Regulating Interdisciplinary Practice, in REGULATION OF THE HeAlthCARE Professions 71 (Timothy S. Jost ed., 1997); Clark C. Havighurst \& James F. Blumstein, Coping with Quality/Cost Trade-Offs in Medical Care: The Role of PSROs, 70 Nw. U. L. REV. 6 (1975) (early work identifying the effect of Medicare's program for reviewing the appropriateness of medical care, and other quality-control standards such as professional licensure, on the range of price-quality combinations available to patients).

118. See William M. Sage, Regulating Through Information: Disclosure Laws and American Health Care, 99 COLUM. L. REV. 1701, 1743-71 (1999) (discussing an "agency rationale" for mandatory information disclosure laws in health care). 
would be gag clauses in managed care contracts, which prohibit physicians from discussing treatments with patients that are not covered by health plans. ${ }^{119}$ Health plans could rationalize the practice as maintaining consumer confidence in their product, and might even muster evidence that disparagement of health plans by physicians is usually inaccurate and/or malicious. But any collective restriction, or restriction by a plan with market power, should be closely scrutinized.

The merger of insurance with delivery of services in managed care systems complicates informational asymmetries regarding quality. It is often in insurers' financial interests to limit the number of individuals with severe medical needs enrolled in their products. Somewhat counterintuitively, a reputation for quality in caring for certain diseases can therefore be disadvantageous to insurers, who would prefer that such individuals go elsewhere. In managed care, insurers frequently can exert control over quality information shared by their constituent providers, which was not the case in a Ptolemaic system. Adverse selection issues can be even more problematic for hospitals and other providers paid a fixed rate based on estimated group medical needs, who may have strong interests in maintaining high quality for their overall patient populations but also may be concerned about attracting a disproportionate share of the sickest patients. Antitrust law should take these issues into account when examining collective informational activities involving managed care.

3. Choice and Standardization.

The foregoing point raises a series of issues with respect to consumer choice in the marketplace. Because the medical profession long maintained that free choice of physician was an essential "ethical" attribute of health care, choice was taken for granted in Ptolemaic formulations of competition and certainly was not linked to market failure. In our empirical sample, moreover, antitrust courts were much more comfortable maintaining a reasonable degree of choice in the market than evaluating linear quality claims of particular competitors, possibly because overseeing consumer choice seemingly requires less technical knowledge of medicine.

However, choice in a multicentric health care system implicates market failures relating to both agency and information, and presents problems of its own. Because of the potential for adverse selection, choice can wreak havoc on insurance markets if discriminatory pricing based on risk is not permitted or is not possible. In addition to the point raised above regarding quality-related information attracting risk, the tendency among private and public payers to offer enrollees a choice of health plans can subject more expensive, higherquality options to adverse selection. Whether adverse selection is best

119. The example is imperfect because, although legislation prohibiting gag clauses is widespread, there is little empirical evidence of their existence. See U.S. GENERAL AcCOUNTING OfFICE ("GAO"), Managed CARE: Explicit Gag Clauses nOt Found in HMO CONTRACTs, But PHYSICIAN CONCERNS REMAIN 2-3 (1997). 
addressed by direct regulation or by collective action involving insurers remains to be determined. Still, antitrust law should be open to the possibility that restricting choice in insurance markets to curtail adverse selection improves the functioning of those markets and therefore improves competition in underlying markets for health services. ${ }^{120}$

Choice is also relevant as it influences price-quality trade-offs. Outside of commodities markets, product differentiation (often through advertising) may shelter producers from price competition. One reason why price competition was a latecomer to medical care is that each professional arguably offers a unique service. Insurers achieved the same result by varying coverage in complex ways, so that price comparisons were harder for consumers to make. Standardizing product features can channel competition into price and linear quality. ${ }^{121}$ By the same token, standardized prices can facilitate comparison shopping based on quality. Because contemporary health care markets are so complex, situations may arise in which allowing every feature of health care markets to vary according to consumer preferences actually reduces competition. This is not to say that antitrust courts should bless naked restraints on trade, but only that they should be receptive to competent evidence regarding pro-competitive effects under circumstances demonstrating lack of competition in the absence of standardization. ${ }^{122}$

Finally, the movement of managed care away from restrictive panels of "brand-name" providers and toward broad, overlapping networks—supposedly the result of market preferences for extensive choice among physicians-may really prove the opposite point, namely that choice is a false proxy for quality. Managed care theorists have frequently hypothesized that an optimally competitive system would allow consumers to choose the degree to which their health plans would incorporate cost considerations into treatment decisions, sometimes called "economic informed consent." ${ }^{23}$ Both patients and physicians

120. Antitrust law may also need to address issues of moral hazard, which can similarly impair the effectiveness of insurance markets. In Smilecare Dental Group v. Delta Dental Plan, 858 F. Supp. 1035 (C.D. Cal. 1994), aff'd, 88 F. 3d 780 (9th Cir. 1996), for example, the court sensibly rejected a claim by a seller of "supplemental insurance" that covered deductibles and co-payments under standard dental insurance that dental insurers were refusing to accept its payments as fulfilling enrollees' contractual obligations, on the grounds that to do otherwise would have made it impossible for the dental insurers to continue to provide their product.

121. For example, health reform proposals based on "managed competition" employed a standard benefit package to promote price competition.

122. There is an obvious tension between this point and our earlier claim that health care markets should move away from provider licensing and towards information-driven, consumer-selected price/quality tradeoffs. How the tension between choice on the provider side and choice on the insurer side of the market should be resolved is open to debate. For example, one wonders if market competition (even with appropriate antitrust deference to welfare-enhancing forms of cooperation) is capable of providing a defensible set of tradeoffs between choice and standardization, or whether this type of problem is better suited for regulatory decision-making.

123. See, e.g., Mark Hall, Making Medical Spending Decisions: The Law, Ethics, and ECONOMICS OF RATIONING MECHANISMS 193-239 (1997) (discussing informed consent to rationing); Arti Rai, Reflective Choice in Health Care: Using Information Technology to Present Allocation 
seem to strongly prefer a unitary standard of medical care, however, along with modal forms of physician compensation (and hence, predictable, incentives regarding under-treatment or over-treatment). Furthermore, exactly what the health system offers consumers at the margin may be less important than consistency, so that tipping points likely exist from one equilibrium position to another. ${ }^{124}$ (In some ways, this is merely a more elegant restatement of the observation that adults tend to be most satisfied with their health plan when it adheres to the style of medical care they experienced as children.) Consequently, patient trust and confidence, and hence, demand for insurance, might be increased by restrictions on variation among plans and providers. If this speculation is borne out by data, it becomes another complication of the Copernican view that courts must from time to time confront.

\section{Public Purchasing.}

Part of the mythos of a physician-centric system is that American health care owes its success to the rugged individualism of the medical profession. ${ }^{125} \mathrm{By}$ contrast, a principal insight of the Copernican view is that government plays a constitutive-not merely regulatory-role in health care markets. This subsection considers the potential role of Medicare and other public payers in ameliorating market failures that impede private competition, particularly regarding quality. The next section applies market failure analysis to regulation qua regulation, specifically the immunity from antitrust scrutiny traditionally extended to state action.

Public dollars comprise roughly half of the $\$ 1.3$ trillion that the United States spends annually on health care. ${ }^{126}$ Not surprisingly, it is widely recognized that public purchasing (Medicare, Medicaid, Federal Employee Health Benefits) and other public funding-including federal tax expenditures-greatly influence price-quality trade-offs in health care and the viability of particular financing and delivery structures. Medicare in particular is the 800-pound

Options, 25 AM. J.L. \& MED. 387, 388 (1999) (discussing electronic technologies and consent to rationing).

124. The present situation reflects an element of historical path-determinism. It suited a variety of political interests for prepaid (HMO) care to be seen from the outset as an "alternative" system to feefor-service medicine, with opportunities for "dual choice." See Gail B. Agrawal \& Howard R. Veit, Back to the Future: The Managed Care Revolution, 65 LAW \& CONTEMP. PROBS. 11, 30-33 (Autumn 2002).

125. Cf. James F. Lally, Letter, 279 JAMA 746, 746 (1998) (criticizing Uwe Reinhardt's belief in universal health insurance). Reinhardt's reply explodes the myth:

Where are these rugged individualists?... Would I find them in the medical profession, whose members rely so heavily on public subsidies for their education and the science they apply, ... who plead with government ... to regulate managed care organizations ... , and who have never balked at using archaic licensure laws to protect their own economic turf?

Uwe E. Reinhardt, In Reply, 279 JAMA 746, 746 (1998).

126. Stephen Heffler et al., Health Spending Projections for 2001-2011: The Latest Outlook, HeALTH AFF., Mar./Apr. 2002, at 207, 209-10 (projecting that $55.2 \%$ of 2003 health spending will be private dollars). If one considers revenue forgone by the Treasury as a public expenditure, the nontaxable status of employer-sponsored health insurance increases the effective percentage of public funding. 
gorilla of the health care system. Medicare's coverage policies are often makeor-break for emerging technologies, and reimbursement rules frequently serve as de facto licensing and scope of practice laws for various health professionals. Although experts have long lamented the political forces that keep Medicare from acting as a market participant, ${ }^{127}$ public payers continue to distance themselves from private market processes. ${ }^{128}$ Correspondingly, antitrust law has indulged the belief that American health care is a private system governed by private competition, even though public purchasing distorts prices, overbuilds capacity (both physicians and facilities), and skews the development and dissemination of technology.

There is an historical irony here. Recall that Arrow's early analysis of health care markets invoked both medical professionalism and government regulation as potential fillers of "optimality gaps" produced by uncertainty. ${ }^{129}$ As already noted, Arrow was ambiguous with respect to the market or nonmarket nature of medical ethics, but in 1963 he could safely assume that government was always a market outsider. ${ }^{130}$ By making government a (very large) purchaser as well as a regulator, Medicare and Medicaid changed that, and created a persistent tension in health care oversight. For example, medical antitrust law developed largely in response to health care as "big business," which would not have been the case absent Medicare. One can even argue that enforcement of antitrust law against medical professionals was in part intended as a competitive solution to a cost problem largely of the government's own making. ${ }^{131}$

For Medicare and antitrust law to ignore one another seems foolish. Instead, competition policy should pay close attention to the purchasing role of government as a source of, or remedy for, private market failure. Some possible improvements are similar to activities already being undertaken by public payers for their own purposes. For example, Medicare has the purchasing leverage and financial resources to obtain widespread participation by health care

127. According to one former Health Care Financing Administration Administrator:

Nothing is more frustrating, ... nor more puzzling to outside observers, than the fact that the payment methods-and even levels of payment-for so many things Medicare purchases are written into law, often at prices higher than a big buyer such as Medicare could obtain in the marketplace.... Medicare suppliers occupy a political territory of classic dimensions ... : narrowly focused interest groups with an enormous specific stake in issues about which the rest of the body politic could really care less.

Bruce C. Vladeck, The Political Economy of Medicare, HeAlth AFF., Jan./Feb. 1999, at 22, 22-30.

128. See Len M. Nichols \& Robert D. Reischauer, Who Really Wants Price Competition in Medicare Managed Care?, HEALTH AFF., Sept./Oct. 2000, at 30 (analyzing Medicare's abortive attempts to adopt private purchasing strategies such as competitive bidding).

129. Arrow, supra note 35, at 947.

130. Medicare and Medicaid were enacted in 1965. 42 U.S.C. $\$ 1395$ (2000).

131. See Havighurst, supra note 29, at 939-40. An interesting question is whether antitrust enforcement became more important merely because health care providers accustomed to Medicare were greedy, or because there was something about the way that government acted as purchaser that increased anti-competitive rents in the private market. The latter conjecture lends support to the Chicago School position that markets work pretty well without antitrust enforcement, unless government itself has done something to impede competition. 
providers in systems for measuring and comparing quality, as well as to educate consumers about how to use that information. Medicare could also use its own information to generate designations of superior quality ("centers of excellence") that would also be useful to private buyers. Similarly, Medicare could invest in risk-adjustment techniques that would allow private employers to counter adverse selection pressures when offering expanded choices to their workers. Somewhat more speculatively, Medicare could be more self-aware about the degree to which private insurers piggyback coverage decisions of new technologies on Medicare's local and national coverage policies. Or Medicare could finally overcome political resistance to selective contracting for health care services and force hospitals, and perhaps even physicians in certain specialties, to bid competitively while meeting specific quality standards, which would provide extremely useful information to the private market. ${ }^{132}$

\section{State Action.}

A striking finding in our empirical review of antitrust litigation was the frequency with which defendants invoked immunity from liability, often on the grounds that the conduct in question had been sanctioned by state government in accordance with Parker v. Brown. ${ }^{133}$ Although there are important constitutional and prudential reasons for the federal government to respect state sovereign decisions regarding competition, ${ }^{134}$ the state action doctrine has from time to time been criticized on economic grounds for its agnosticism toward the relationship between state regulation and market function. ${ }^{135}$

The state action doctrine is problematic to both Ptolemaic and Copernican accounts of medical competition. Ptolemaic views base their discomfort with sweeping state action protection on the observation that, particularly at the state level, much regulation is either explicitly delegated to the medical profession or enacted with such deference to their views that it cannot properly be regarded as democratic. To some degree, this is inevitable where the professions are concerned: Lack of independent state expertise means that nominally

132. Because they tend to be major employers in most communities, hospitals have been able to exert sufficient political power to derail attempts by Medicare to experiment with competitive bidding or other selective contracting models. Thus far, bidding has been successfully applied only to durable medical equipment manufacturers, which lack equivalent demographic influence. See Bryan Dowd et al., A Tale of Four Cities: Medicare Reform and Competitive Pricing, HEALTH AFF., Sept./Oct. 2000, at 9, 24-25.

133. 317 U.S. 341 (1943). See Hammer \& Sage, supra note 7, at 581-82 (seventeen percent of judicial opinions considered state action immunity). See generally SULLIVAN \& HARRISON, supra note 101, at 90-103. Defendants also frequently claimed immunity under the political action (NoerrPennington) doctrine, the implications of which we discuss below. See infra notes 166-167 and accompanying text.

134. For example, engaging the federal judiciary in determining the degree to which state regulation impairs some theory of free market exchange bears a disturbing resemblance to substantive due process review in the Lochner era. See James F. Blumstein \& Terry Calvani, State Action as a Shield and a Sword in a Medical Services Antitrust Context: Parker v. Brown in Constitutional Perspective, 1978 DUKE L.J. 389, 420-22 (1978).

135. See, e.g., AREEDA AND HovENKAMP, supra note 79, at 230 (identifying market failure as an alternative approach to state action immunity). 
public efforts to define standards, craft regulations, and implement policy depend heavily on professional involvement. Nevertheless, it seems inconsistent from an antitrust perspective to subject openly self-regulatory activities to substantive evaluation for their effects on competition, while excusing tacitly self-regulatory activities from review if attributable to the state acting in its sovereign capacity. Particularly questionable under the circumstances is the doctrinal requirement for active state supervision, which is applied to state laws extending antitrust immunity to private parties, because expert professional activities can seldom be supervised meaningfully. Consequently, medical antitrust scholars have focused their attention mainly on professional licensing boards and similar governmental or quasi-governmental bodies, and to a lesser extent on recent statutes conferring "certificates of public advantage" on hospital mergers or similarly attempting to shield medical providers from antitrust exposure. ${ }^{136}$

A Copernican view shares this skepticism, mainly because physicians have maintained political power at the state level disproportionate to their economic influence. As a result, the Ptolemaic view has greater currency where politically determined market failures are concerned than where the failures inhere in the private competitive process. ${ }^{137}$ Medical antitrust policy, therefore, would be better served by moving toward a unitary evaluation of both professional selfregulation and state regulation dealing with similar subjects. ${ }^{138}$ Specifically, we advocate abandoning the active state supervision requirement of the existing state action doctrine and subjecting both self- and state-regulation to substantive antitrust scrutiny as to their likely effects on market failure. ${ }^{139}$ Such a change is not intended to eviscerate existing regulation. Rather, the goal is to encourage both regulation and self-regulation that improves the functioning of medical markets, especially with respect to quality-based competition.

136. Frank P. Grad, The Antitrust Laws and Professional Discipline in Medicine, 1978 DUKE L.J. 443, 454-64, 472-77 (1978) (discussing potential antitrust challenges to medical board activities); Fred J. Hellinger, Antitrust Enforcement in the Healthcare Industry: The Expanding Scope of State Enforcement, 33 HEALTH SERVICES RES. 1477, 1480-86 (1998) (summarizing the recent activities of states that have attempted to exempt health care conduct from antitrust liability under the state action doctrine); GAO, HeAlth CARE: Federal and State ANTITRust Actions Concerning the HEALTH CARE INDUSTRY 10-13 (1994) (detailing the efforts of states to afford hospitals and other health care providers immunity under the state action doctrine).

137. One could make a similar point about public purchasing at the federal level, especially when one considers the fact that many of the factors that hamstring Medicare as a market participant derive from concessions made to secure the AMA's political support in 1965. See, e.g., 42 U.S.C. $§ 1395$ (2000) (prohibiting federal interference with medical practice) 42 U.S.C. $§ 1395$ a (2000) (assuring free choice of physicians by patients).

138. In this connection, it is worth noting that most of the restrictions on dental advertising imposed as a self-regulatory matter by the California Dental Association were not significantly different from those specified in the California Business \& Professions Code. Cal. Dental Ass'n v. FTC, 526 U.S. 756, 760 n.1 (1999).

139. John S. Wiley, Jr., A Capture Theory of Antitrust Federalism, 99 HARV. L. REV. 713, 739-76 (1986) (arguing that state action immunity should not apply to restraints on trade that arose from provider "capture" of regulators, did not address a substantial market failure, and were not specifically exempted by Congress). 
A Copernican approach offers two additional justifications for a similar result. First, because protection of public health and safety is a traditional application of state police powers, the state action doctrine has the undesirable effect of partitioning quality concerns from the competitive process. Subjecting state regulation to market failure review would reinforce the point that quality is an intrinsic aspect of medical markets. Second, as will become apparent in the discussion below, a Copernican analysis posits that sound competition policy requires connecting antitrust oversight with regulatory processes beyond demand-side effects on market failures. This approach entails examining the effects of various market conditions on total social welfare, which should also be the relevant criterion for democratic decision-making. Applying substantive review to state action would test the integrity of the political processes at work in regulating health care and would tend to reveal distortions produced by interest-group models of public choice.

These considerations could be addressed to a degree by measures that do not completely overturn the existing state action doctrine. For example, a federal requirement (framed in a constitutionally permissible manner) that states issue a competition impact statement in connection with particular types of health care regulation might educate both legislators and market competitors. Over time, however, it might be advisable to move toward more comprehensive federal regulation of competitive conditions in health care, which would at least pre-empt narrow state regulations that can be shown to retard competition primarily to serve private interests. ${ }^{140}$

\section{Beyond Traditional Market Failure}

The market failure considerations discussed above primarily involve demand-side effects and the interactions between identifiable buyers and identifiable sellers of health care services. By contrast, certain collective action problems affect the health care production function, so that solving them potentially confers social benefits by shifting the supply curve as well. ${ }^{141}$ Some, like incomplete information and medical innovation, involve partial public goods.

140. Although line-drawing would inevitably be very difficult, one could imagine a "state plan" mechanism that allowed states to demonstrate that their own regulatory approaches to health care were sufficiently cohesive to receive federal deference. Under the Clinton administration's failed health reform proposal, for example, states that decided to implement a comprehensive "single-payer" system were entitled to opt out of the more market-based federal regime. Health Security Act, H.R. 3600, 103d Cong., 1st Sess., §§ 1221-24 (1993) (setting forth requirements for state single-payer systems).

141. The production function is critical in health policy in part because, as Arrow observed, various market failures render the process of delivering medical care synonymous with the care itself. See Arrow, supra note 35, at 949 ("[T] he product and the activity of production are identical."); see also Lawrence R. Jacobs, Politics of America's Supply State: Health Reform and Technology, HEALTH AFF., Summer 1995, at 143, 146-52 (analyzing the political failures that prevent the United States from employing supply-side constraints on health care); Thomas Rice, Can Markets Give Us the Health System We Want?, 22 J. HEALTH POL. POL'Y \& L. 383, 416 (criticizing market approaches to health policy because they focus exclusively on influencing demand, not supply). 
Others, like risk-segmentation and therapeutic trust, involve negative externalities.

These issues are currently addressed, if at all, in self-regulatory or regulatory, rather than competitive terms. In fact, many of these issues represent social concerns that, under Ptolemaic conditions, were entrusted to the medical profession either directly (for example, the physician-patient relationship) or indirectly (for example, public funding for scientific innovation and clinical dissemination). By and large, physicians support incorporating such concerns into overall health system governance in the future, but they are understandably uncomfortable with the notion that physicians will no longer have exclusive control over how these values are reflected in the health care system-which inevitably suggests some criticism of the way the profession has handled them to date.

Can social concerns over system productivity and performance be brought within an economic framework, which remains the lingua franca of antitrust even under Copernican assumptions? $?^{142}$ To do so, one would have to make changes to both antitrust doctrine and the nature of evidence deemed admissible in court. Specifically, one would need to adopt a total social welfare standard for judging the efficiency of putative restraints on trade, which would allow harm to consumers as a second-best solution as long as efficiency gains within the health care system exceeded losses. ${ }^{143}$ One might even need to impose distributional requirements with respect to the disposition of net gains. These considerations raise complicated questions concerning public-private interaction over the scope, composition, and character of markets, and serve as a reminder that markets are also social institutions. Interventions in this context create opportunities for potentially welfare-enhancing private collaboration and constructive forms of public intervention, but also risk debilitating market failure and anti-competitive manipulation.

It is also a close question whether these issues can be factored into antitrust oversight without corrupting the objectivity of economic analysis. On the one hand, traditional economics is well validated as an empirical tool; on the other hand, economic rhetoric can be socially constructed to serve normative goals. ${ }^{144}$ Overall, however, our empirical work suggests the importance in health care of bringing competition and regulation into proximity at an interface, not a

142. They can certainly be brought in if one revives early understandings of antitrust law as designed to preserve economic structures that foster democracy rather than efficiency, and the welfare of people as citizens rather than consumers. This idea still appeals to communitarians. See, e.g., Michael J. Sandel, The Constitution of the Procedural Republic: Liberal Rights and Civic Virtues, 66 FORDHAM L. REV. 1, 6-11 (1997).

143. See Hammer et al., supra note 86, at 853-75 (explaining "intramarket" second-best solutions).

144. See Avery W. Katz, Positivism and the Separation of Law and Economics, 94 MiCH. L. REV. 2229, 2240-50 (1996) (distinguishing normative from positive welfare economics); Uwe E. Reinhardt, Can Efficiency in Health Care be Left to the Market?, 26 J. HeAlTH POL. POL'Y \& L. 967, 981-84 (evaluating the Kaldor-Hicks efficiency criterion in normative terms); see also Paul Menzel et al., Toward a Broader View of Values in Cost-Effectiveness Analysis of Health, HASTINGS CENTER REPORT May, 1999 at 7 (arguing in favor of adapting cost-benefit analysis to reflect atypical social preferences). 
boundary, and we believe that the factors discussed below help define that interface. Still, we acknowledge that extending antitrust analysis to issues beyond transactions between individual buyers and sellers risks drowning in a flood of good intentions. Furthermore, untethering antitrust courts from conventional economics may render them both standardless and unaccountable as legal institutions. ${ }^{145}$ We therefore reiterate that, although we are obviously not devotees of the Chicago School, neither are we regulatory wolves clad as competitive sheep. ${ }^{146}$

1. Medical Knowledge.

Lack of information is usually considered a demand-side market failure. For example, providing information about quality to consumers reduces uncertainty associated with purchasing, which can both increase aggregate demand and channel demand to higher quality providers. In health care, as discussed above, informational asymmetries between physicians and patients, and among newer participants in medical markets, are theoretically compatible with this understanding.

It has become clear in recent years, however, that the informational base of health care is not only asymmetric, but grossly incomplete. ${ }^{147}$ Large, unexplained, regional variations exist in treatment of common diseases, which have proved resistant to correction through conventional mechanisms for disseminating new research findings. Variation is compounded by the absence of economic incentives for rationalizing American medicine during most of the past half-century. ${ }^{148}$

Because care is over-used and misused in many settings, quality improvements, in theory, may decrease health expenditures rather than increase them. ${ }^{149}$ The prospect of providing comparable, or even higher, levels of quality at

145. The Sherman Act is unusual among federal statutes for its generality. Enforcement is therefore a "common law" endeavor, which unsettles the Supreme Court as much as it empowers lower courts to address the equities of specific cases. The Court has been unwilling to risk similar expansions of federal common law adjudication in other areas of health care. In Pegram v. Herdrich, 530 U.S. 211, 231-37 (2000), for example, the Court seemingly allowed its visceral distaste for federal common law to justify abdicating responsibility for specifying employers', health plans', and possibly even physicians' roles as ERISA fiduciaries. See Sage, supra note 103, at 221-22 (discussing Pegram). See generally Peter L. Strauss, Courts or Tribunals?: Federal Courts and the Common Law, 53 ALA. L. REV. (forthcoming 2002) (urging the restoration of "judging" authority to federal courts).

146. Perhaps we should draft a truly Copernican preface to this article and address it to Judges Posner and Easterbrook rather than the Vatican!

147. See Sage, supra note 118, at 1771-80 (discussing incomplete information and the desirability of improving health system productivity as a justification for mandatory information disclosure laws).

148. See R. Adam Dudley et al., The Impact of Financial Incentives on Quality Health Care, 76 MiLBANK Q. 649, 661-62 (1998) (linking financial arrangements in fee-for-service and prepayment with incentives to underprovide and overprovide care); Mark R. Chassin \& Robert W. Galvin, The Urgent Need to Improve Health Care Quality: Institute of Medicine National Roundtable on Health Care Quality, 280 JAMA 1000, 1002 (1998) (discussing problems associated with the misuse of care).

149. See Jane E. Sisk, Increased Competition and the Quality of Health Care, 76 MiLBANK Q. 687, 691 (1998) ("Studies have not found a consistent relationship between the cost and quality of medical providers. For example, studies of ambulatory practices caring for Medicare beneficiaries in Maryland found that technical quality varied by the type of facility, but not its costliness."). 
reduced costs was a major moral justification for the growth of managed care and was often associated with proposals for "clinical practice guidelines" that improved overall clinical benefit as well as cost-effectiveness. ${ }^{150}$ This effort has produced only modest successes. Part of the explanation lies in the fact that, despite their scientific veneer, guidelines are often consciously or unconsciously motivated by self-interested biases as to what constitutes appropriate clinical care. However, another part stems from insufficient incentives to invest in these processes, because gains cannot easily be appropriated by the innovator. This public goods aspect of health care production suggests that a competition policy seeking to maximize total social welfare would look favorably on collective strategies for knowledge generation (figuring out the right thing to do) and dissemination (getting people to do it).

One aspect of this process likely involves the formation of large firms or clinically integrated networks, even if they come at some cost to consumers in terms of market concentration. ${ }^{151}$ Paralleling our notion of a Copernican transformation in health care, the growing literature on medical errors and patient safety rejects the traditional focus on individual physician behavior and emphasizes system-based accountability and improvement, ${ }^{152}$ often associated with larger institutions. ${ }^{153}$ Our empiric review of antitrust litigation may shed some light on this question. We observed a large number of cases in which courts rejected antitrust challenges to hospitals' efforts to control physician practice, usually through exclusive contracting. ${ }^{154}$ We analogize these cases to modern antitrust treatment of vertical restraints between manufacturers and dealers or distributors in other industries, which allows restrictions on intra-brand competition in order to improve inter-brand competition. ${ }^{155}$ In the usual distribution case, however, the justification for intra-brand restrictions is to induce dealers to invest in brand promotion, offer free service, and provide other nonprice benefits by solving the free rider problem among them. Physicians, by contrast, do not need similar encouragement regarding nonprice competition. What they do require is coordination aimed at improved productivity. ${ }^{156}$

150. Robert H. Brook et al., Measuring Quality of Care, 335 NEW ENG. J. MED. 966, 968 (1996) (discussing the role and function of clinical guidelines).

151. In this respect, the 1996 Joint Policy Statements issued by FTC and DOJ were quite forwardlooking, although the agencies were dealing with the practicalities of joint ventures among health care providers rather than large normative issues. See 1996 Department of Justice and Federal Trade Commission Statements of Antitrust Enforcement Policy in Health Care, 4 Trade Reg. Rep. (CCH) II13,153, at 20,814 (Aug. 5, 1996).

152. See generally Institute OF Medicine, To ERR Is Human (Linda T. Kohn et al. eds., 2000).

153. William M. Sage, Principles, Pragmatism, and Medical Injury, 286 JAMA 226, 227 (2001) (observing that "[Studdert and Brennan's] argument implies that a superior form of medical organization exists"); David M. Studdert \& Troyen A. Brennan, No-Fault Compensation for Medical Injuries: The Prospect for Error Prevention, 286 JAMA 217, 219-20 (2001) (advocating institutional accountability for medical error).

154. See Hammer \& Sage, supra note 7, at 613-14.

155. See Hammer, How Doctors Became Distributors, supra note 40.

156. One can regard Ambroze v. Aetna Health Plans in this light. No. 95 CIV. 6631, 1996 U.S. Dist. LEXIS 7274 (S.D.N.Y. May 28, 1996). The physician plaintiffs argued that Aetna's ban on balance billing was preventing them from offering higher-price, higher-quality services to patients. Id. at *14. 
2. Technology and Political Action.

Technological innovation suffers from a different set of problems. As Lawrence Jacobs points out, the United States differs from all other industrialized nations in its adamant refusal to impose supply-side constraints on medical technology. ${ }^{157}$ To the contrary, generous government policies regarding basic research funding, incentives for technology transfer, and reimbursement under Medicare have resulted in unparalleled innovation and dissemination of patentable medical technology. ${ }^{158}$ Although some commentators consider this proliferation of property rights efficient, ${ }^{159}$ it is also possible that it has gridlocked efforts to rationalize innovation and improve overall system productivity. ${ }^{160}$ Oddly, one might view the non-profit hospital merger cases, which are otherwise aberrant in their seeming rejection of core economic principles of antitrust law, as more progressive in terms of technology and productivity. ${ }^{161}$ The medium-sized markets where most of these cases take place may regard the presence of sophisticated technology within the community as an on-off proposition, in which case the merger may seem to reduce duplication, free up resources to acquire skills or equipment not currently available, and facilitate rational planning.

Earlier discussions of public purchasing and state action demonstrated that governmental policies can have unpredictable and untoward effects on competition in health care. In other words, political failure frequently compounds market failure. Incentives for strategic manipulation of public processes are perhaps most intense where (1) the government action creates a product or market that would otherwise not exist; and (2) the stakes are structured in a zero-sum fashion-action in favor of one competitor comes at the sake of another competitor. Whereas any qualified provider can feed at the Medicare trough, for example, only one company can lay claim to an exclusive patent right. Moreover, private purchasing and payment decisions are often linked to public judgments, creating perverse incentives. ${ }^{162}$ While it would be neither pos-

The court could have justified the practice as fostering interbrand competition between Aetna and other health plans by forcing physicians to reduce non-price competition and improve costeffectiveness.

157. See Jacobs, supra note 141, at 145-46.

158. See Rebecca Eisenberg, The Shifting Functional Balance of Patents and Drug Regulation, HEALTH AFF., Sept./Oct. 2001, at 119, 121-24 (examining how patents and regulation act in tandem to limit competition for prescription drugs).

159. See J.D. Kleinke, Oxymorons: The Myth of a U.S. Health Care System (2001) (criticizing efforts to improve efficiency through managed care and praising technologic innovation).

160. Cf. Michael A. Heller, The Tragedy of the Anticommons: Property in the Transition from Marx to Markets, 111 HARV. L. REV. 621 (1998) (analyzing the observation that property rights can create collective action problems as well as solve them).

161. See, e.g., FTC v. Butterworth Health Corp., 946 F. Supp. 1285 (W.D. Mich. 1996) (allowing merger to monopoly of the two largest hospitals in Grand Rapids on the theory that, as non-profit institutions, they would not abuse market power).

162. For example, the manufacturer of Claritin, Schering-Plough, has been arguing to the FDA that its product is too dangerous to be sold without a prescription. Its motive for doing so is the fact that, if Claritin is authorized for over-the-counter sale, private insurers will stop covering it, forcing the manufacturer to reduce its price. Predictably, the insurers argued to the FDA that Claritin is safer than 
sible nor desirable to have federal antitrust law operate in a counter-majoritarian, apolitical vacuum, the extent to which politics influences health care markets suggests the need for more actively policing strategic and anti-competitive behavior at the private-public regulatory interface controlling biotechnology, pharmaceuticals, and medical devices.

Our empirical findings reveal insufficient attention by antitrust courts to technological innovation. ${ }^{163}$ Few private plaintiffs litigate these cases, and judges often defer the innovation-related antitrust claims that are asserted to other legal forums, such as the Patent Office, the FDA, Medicare coverage determinations, or the International Trade Commission (ITC), which enforces United States trade law. ${ }^{164}$ A particular obstacle to innovation-based antitrust litigation is that plaintiffs fail to meet legal requirements regarding standing and antitrust injury, usually because potential innovators who are being deterred by current competitors may not yet be in the market, and, in any event, their damages are speculative. ${ }^{165}$

Furthermore, a significant number of defendants successfully argue that their conduct is shielded by the Noerr-Pennington doctrine, which protects political action even if engaged in collectively by competitors, and even if it produces anti-competitive effects. ${ }^{166}$ In recent years, the Supreme Court has so narrowly construed the sham exception to the Noerr-Pennington doctrine that it is virtually impossible to maintain an antitrust suit if there is the slightest objec-

common antihistamine medications such as Benadryl. The FDA recently recommended that over-thecounter sale be allowed. See Milt Freudenheim \& Melanie Petersen, The Drug-Price Express Runs Into $a$ Wall, N.Y. TIMES, Dec. 23, 2001, at C1.

163. See Hammer \& Sage, supra note 7, at 626-31.

164. The federal enforcement agencies have paid closer attention to the connection between antitrust law and medical innovation and have litigated major cases involving pharmaceuticals and medical devices, perhaps because they were under pressure from Congress not to target only physicians and hospitals.

165. See, e.g., Barton \& Pittinos v. SmithKline Beecham, 942 F. Supp. 235 (E.D. Pa. 1996), aff'd, 118 F.3d 178 (3rd Cir. 1997) (involving a pharmaceutical marketing company that was developing a new method of marketing and distributing hepatitis-B vaccine to nursing homes); Practice Perfect, Inc. v. Hamilton County Pharm. Ass'n, 732 F. Supp. 798 (S.D. Ohio 1989) (involving a prescription repackaging business that prepared labels and dosages for drugs and sold them to physicians, who would then sell the drugs directly to patients).

166. Some Noerr-Pennington cases arise in patent disputes, see C.R. Bard, Inc. v. M3 System, Inc., 157 F.3d 1340 (Fed. Cir. 1998) (reversing trial verdict and holding that the patent suit was not objectively baseless and therefore could not constitute sham litigation); Mitek Surgical Prod., Inc. v. Arthrex, Inc., 21 F. Supp. 2 d 1309 (D. Utah 1998) (granting plaintiff's motion for summary judgment on defendant's counterclaim, holding that the patent infringement suit was not objectively baseless); and Boston Sci. Corp. v. Schneider, 983 F. Supp. 245 (D. Mass. 1997) (holding that underlying patent litigation suits were immune from antitrust challenge because they were not objectively baseless), others concur immunized proceedings before the FDA, see Mylan Labs., Inc. v. Akzo, N.V., 770 F. Supp. 1053 (D. Md. 1991) (antedating Professional Real Estate, the court held that the defendant's efforts to gain FDA approval for their generic drugs using an ANDA constituted Noerr-protected conduct), while others find immunized conduct before the International Trade Commission ("ITC"), see Cheminor Drugs, Ltd. v. Ethyl Corp., 168 F.3d 119 (3rd Cir. 1999) (finding an independent objective basis existed for ITC suit and therefore that conduct was immunized); Bio-Technology Gen. Corp. v. Genentech, Inc., 886 F. Supp. 377 (S.D.N.Y. 1995) (holding that ITC proceedings were not objectively baseless and were therefore Noerr-protected). 
tive merit to the defendant's action. ${ }^{167}$ The policy problem is that there is a wide range of behavior that may have an objective legal basis as understood by the courts, but where the intended purpose is to leverage the government process to achieve private, anti-competitive objectives. Without antitrust accountability, however, there are few meaningful sanctions that can be applied by the Patent Office, the FDA, or the ITC to discourage abuses.

The anti-competitive implications of Noerr-Pennington for health care have not escaped notice in the legal literature, but have been interpreted in Ptolemaic terms. ${ }^{168}$ When one views the health care system as physician-centered, the problem is that physicians could collectively "petition" state medical boards and other quasi-governmental bodies that were themselves dominated by physicians, with the result that blatant cartel behavior would be exempt from scrutiny. ${ }^{169}$ The proposed remedy for this situation-as for state action defenses under similar circumstances-would be to disqualify physician-controlled bodies from the protected category of public decision-makers.

Copernican analysis reveals a more extensive problem, with the worst risks to competition arising from political action involving winner-take-all, patented medical innovations, albeit before legitimate public agencies. To remedy the situation, antitrust law might revive an economics-based balancing test proposed in some earlier appellate cases: whether the expected benefit from the petitioning activity, calculated as the direct benefit from government action discounted by the probability of obtaining it, exceeds the costs associated with petitioning. ${ }^{170}$ Alternatively, one could devise a standard to prevent parties from bootstrapping partially legitimate claims into larger attacks against competitors by predicating antitrust liability on establishing that the political action requested exceeded in scope what was justified by the objectively legitimate basis for petitioning.

3. Insurance, Access to Health Services, and Social Welfare.

With insurance, the traditional information asymmetry in health care is turned on its head-consumers typically have better information as to their medical risk than insurers. This invites a range of strategic behavior on both sides of the transaction: Consumers are susceptible to moral hazard and adverse selection, while insurers exploit these tendencies in addition to defending against them. For example, insurers may encourage high risk patients to disenroll, and may market selectively and structure benefits so as to attract rela-

167. See Professional Real Estate Investors, Inc. v. Columbia Pictures Indus., Inc., 508 U.S. 49, 60 (1993).

168. See Mark A. Thimke, Physician Influence: Applying Noerr-Pennington to the Medical Profession, 1978 DUKE L.J. 701, 705-26 (1978) (discussing the doctrine's limited applicability to quasipublic self-regulatory organizations).

169. See id.

170. See Premier Elec. Const. Co. v. Nat'l Elec. Contractors Ass'n, 814 F.2d 358, 372 (7th Cir. 1987) (opinion by Judge Posner suggesting that cost-benefit analysis can distinguish lawful from unlawful litigation); Grip-Pak, Inc. v. Ill. Tool Works, Inc. 694 F.2d 466, 472 (7th Cir. 1982) (opinion by Judge Easterbrook taking the same approach). 
tively healthy people. ${ }^{171}$ If the relationship between pricing and risk becomes too attenuated, the insurance pool may collapse.

Insurance market failures were well known in Ptolemaic accounts of health care competition. Early health insurance markets, however, were often captive financing vehicles for medical providers (Blue Cross for hospitals and Blue Shield for physicians), were sometimes subject to premium regulation that took the edge off competitive impulses, and were under only mild pressure from consumers to keep prices low. ${ }^{172}$ As a result, insurance funded the physician-patient relationship but rarely interfered with it, and the tools medicine had at its disposal to treat the sick were usually so limited that they were available through charity (or at least cross-subsidization) if patients were for some reason uninsurable. Insurance market failures grew central to policy analysis only when cost became of sufficient concern, mainly to employers as health plan sponsors, that insurers were forced to compete on price by involving themselves directly in the provision of medical services. ${ }^{173}$

With the advent of managed care, however, competition in the insurance aspect of health coverage may be in tension with competition in the service aspect. A modern health plan can be price-competitive in two distinct ways: by rendering care efficiently, and by keeping sick people out. Not surprisingly, health plans will tend toward the latter course if the relative profitability of manipulating risk pools is significantly greater than that of improving the costeffectiveness of clinical care. ${ }^{174}$ There is also the potential for direct harm if consciously providing lower quality care to selected high-risk patients hastens their disenrollment.

A Copernican perspective recognizes that enhancing social welfare by improving the "productivity" of the health care system requires consensus on exactly what it produces. Is a health insurance system that makes cheap coverage available to healthy people "productive?" Or is such a system only productive if it delivers more and better health care? This is a social question that is far from settled. ${ }^{175}$ As a result, combined products such as those offered by

171. Sisk, supra note 149 , at 700.

172. See, e.g., STARR, supra note 42, at 290-334 (describing health insurance between 1930 and 1950).

173. This was predicted by Arrow. See Arrow, supra note 35, at 962 (noting that, because of moral hazard, "market forces, therefore, tend to be replaced by direct institutional control").

174. Some commentators paint a fairly dire portrait. "There is also the inescapable conflict generated by the fact that in our current system, strategies to avoid risky patients will almost certainly yield more cost savings than strategies to improve quality." Marcia Angell \& Jerome P. Kassirer, Quality and the Medical Market Place_Following Elephants, 335 NEW ENG. J. MED. 883, 883 (1996). No health plan can be successful by consciously cultivating a reputation of providing inferior care in the aggregate. The competitive demands for "quality" are quite strong. Tradeoffs between risk selection and quality are more likely to appear on the margins, such as in the structure of plan benefits or in the treatment of particular subpopulations.

175. Recent scholarship on insurance emphasizes its chimerical properties, and the variability of social responses to it. See Tom Baker \& Jonathan Simon, Embracing Risk: The Changing Culture of Insurance and Responsibility (2002) (collecting essays suggesting that insurance both affects and is affected by other social issues); see also William M. Sage, Insurance and the Moral Plurality, HEALTH 
today's health plans generate a range of expectations, many of them inconsistent, and create significant difficulties for both private transactions and public oversight.

Even if a Copernican view of antitrust tolerates potentially anti-competitive activity that overcomes market failure, whether the market has failed depends on what the market is. Should antitrust look favorably on conduct that suppresses risk-based competition, ${ }^{176}$ or should it attempt to maintain market availability of both risk-based and service-based insurance products? The existing framework for insurance industry supervision adds complexity to the task. "Core" aspects of insurance-such as sharing actuarial information that enhances estimation of risk-are expressly exempted from federal antitrust law by the McCarran-Ferguson Act, ${ }^{177}$ which was motivated by a desire to leave insurance regulation to the states at a time when understandings of trade and commerce would otherwise have swept insurance into a competitive framework overseen by the Sherman Act. ${ }^{178}$ By contrast, activities by health insurers that relate to service delivery, such as contracting with medical providers, are typically subject to federal antitrust enforcement. ${ }^{179}$

Finally, how does one address concerns about unequal access to health care? These considerations seem an odd fit with competition policy, but there is little doubt that health system "productivity" can reasonably be defined to encompass them, both at the level of individual patient care and at the level of society. Reputable accounts of health insurance regard it as a statement of social solidarity. ${ }^{180}$ People value charity, and suffer when others' suffering is not relieved. Within individual therapeutic relationships, trust has both intrinsic and instrumental value ${ }^{181}$ and "pick-your-poison" forms of competition can be "anti-trust" in this sense of the term. All of these factors raise the possibility that overtly competitive health insurance systems that emphasize value-for-money rather

AFF., Mar./Apr. 2002, at 294, 295 (reviewing Baker and Simon's Embracing Risk and noting that pluralism regarding the meaning of insurance suggests that "change will be possible only through coalition, not consensus").

176. Various forms of risk adjustment are the most commonly touted solution to risk-selection problems: "The overall goal should be to convince plans that they will receive for each enrollee a payment that accurately reflects the amount of money an efficient plan would need to provide highquality care to a patient with the enrollee's medical problems." Dudley et al., supra note 148, at 677-78. Risk adjustment, however, raises notoriously difficult technical as well as practical problems. See Joseph P. Newhouse et al., Risk Adjustment and Medicare: Taking a Closer Look, HEALTH AFF., Sept./Oct. 1997, at 26, (discussing limitations of existing risk adjusters and the efforts to risk adjust Medicare managed care programs).

177. 15 U.S.C. $\S \S 1011-1015$ (2000).

178. See generally Charles D. Weller, The McCarran-Ferguson Act's Antitrust Exemption for Insurance: Language, History and Policy, 1978 DUKE L.J. 587 (1978).

179. See, e.g., Group Life \& Health Ins. Co. v. Royal Drug Co., 440 U.S. 205 (1979) (holding that agreements between insurers and pharmacies were not the "business of insurance," and therefore not protected by the McCarran-Ferguson Act from antitrust attack).

180. Deborah A. Stone, The Struggle for the Soul of Health Insurance, 18 J. HEALTH Pol. POL'Y \& L. 287, 290-94 (1993) (distinguishing social solidarity visions of insurance from private risk-reduction).

181. See Mark A. Hall et al., Trust in Physicians and Medical Institutions: What Is It, Can It Be Measured, and Does It Matter?, 79 MiLbANK Q. 613, 613 (2001). 
than compassion, whether tied to risk or to service delivery, harm the aggregate "production function" and, therefore, can be welfare-reducing. ${ }^{182}$

The non-profit hospital merger cases capture some of these values in antitrust litigation, though admittedly in ways that strain legal doctrine and economic analysis. In FTC v. Butterworth Health Corp., for example, the court looked to the interests of potential consumers as well as actual ones, and included in the former category individuals who cannot afford medical care but nonetheless need it. ${ }^{183}$ In addition, the court's impassioned defense of the virtues of non-profit hospitals can be seen as a reaction to the implicit accusation by the enforcement agencies that the merger was ill-motivated as well as economically anti-competitive. To the communities where health facilities and professionals are located, believing in their good intentions is part of benefiting from their services. Competition policy should at least recognize these beliefs and effects. While it is doubtful that private markets will ever independently produce levels of coverage and access that meet social expectations, this does not mean that it is never desirable to use markets as a tool to achieve social objectives where markets have a strong comparative advantage over regulatory alternatives, perhaps by manipulating the initial conditions under which markets operate.

\section{$\mathrm{V}$ \\ CONCLUSION}

In this article, we have used the analogy of Copernican astronomy to suggest that understanding the dramatic change wrought by managed care requires a conceptual reorientation regarding the meaning of competition in health care and its appropriate legal and regulatory oversight. Although the astronomer's revolution, which aims only to account for what exists, differs fundamentally from the policy-maker's revolution, which seeks not only to describe but to improve, both share the belief that misperceiving the world around us limits our potential for technical and social progress. We believe that the American health care system's relatively recent embrace of competition-while a dramatic event-may be failing because it was not accompanied by an accurate understanding of the system's dynamic structure, particularly with respect to quality. We believe that conventional antitrust oversight should give way to a more holistic competition policy-not only to account factually for managed care, but also to secure the gains that have been achieved and move productively ahead. The unacceptable alternative is to allow complexities and contradictions to accumulate to the point that society despairs of resolving them and retreats into

182. Relaxing the intramarket second-best limitation, it is also worth pointing out that health may increase social wealth through enhanced overall productivity, as well as wealthier people simply being healthier. See David E. Bloom \& David Canning, The Health and Wealth of Nations, 287 SCIENCE 1207, 1209 (2000).

183. FTC v. Butterworth Health Corp., 946 F. Supp. 1285, 1299-1300 \& n.5 (W.D. Mich. 1996). 
[Vol. 65: No. 4

nostalgia or worse. It would be a great tragedy for the "Managed Care Revolution" to be followed by the health care equivalent of the "Cultural Revolution." 